\title{
EINSTEIN $^{1}$
}

\section{THE RIGHT TO SELF-DEFENCE IN NATIONAL AND INTERNATIONAL LAW: THE ROLE OF THE IMMINENCE REQUIREMENT}

\section{Onder Bakircioglu*}

This article explores the doctrine of self-defence within the context of the challenges directed at the imminence requirement, from the perspective of both national and international law. The article will attempt to illustrate that the requirement of imminence underlines the political character of the self-defence doctrine wherein private force may only be resorted to in the absence of institutional protection. This study will argue that the imminence rule can not merely be regarded as a "proxy" for establishing necessity; rather, the elements of imminence, necessity, and proportionality are inextricably connected to ensure that defensive force is only resorted to when national or international authorities are not in a position to prevent an illegal aggression, and that the defensive lethal force is not abused.

\section{INTRODUCTION}

The September 11 attacks aroused controversy as to whether anticipatory or pre-emptive self-defence ${ }^{2}$ is allowed under customary international law, and if so, under what circumstances. Following the devastating attacks on New York and Washington, the 2002 National Security Strategy (NSS) made it clear that the United States would act unilaterally to protect its security against "emerging threats before they are fully formed."3 This approach signified a radical departure from the collective security system by the sole existing super power. Indeed, while the right to national self-defence has been recognized as an inherent right of states since the very emergence of international law,

* Onder Bakircioglu, Lecturer in Law, Queen's University Belfast. The author is indebted to Professor Caroline Fennell for her constructive comments on earlier drafts of this article.

1. Official Report of the Proceedings of the Twenty-Fourth Republican National Convention 165 (1948);.CAMERon Hunt, PAX Unita 96 (2006).

2. In this study these terms will be used interchangeably as a distinct category from preventive wars.

3. David Adler, George Bush and the Abuse of History: The Constitution and Presidential Power in Foreign Affairs, 12 UCLA J. INT'L L. \& FOREIGN AFF. 75, 121 (2007). 
according to the United Nations Charter, ${ }^{4}$ states are prohibited from resorting to defensive force unless the threat is actual or imminent and the Security Council is unable to contain the situation.

The Bush Administration, however, argues that modern warfare and recent innovations in military technology, which may also be employed by nonstate actors engaged in terrorist activities, changed the whole calculus of selfdefence. ${ }^{5}$ Warfare warfare is now much more devastating and can occur with less warning, which gives considerable advantage over an opponent if allowed to strike first. It would thus be unreasonable and unrealistic to employ the orthodox principles governing the right to self-defence, namely to await the occurrence or the threat of an imminent "armed attack" to use defensive force. Nations threatened by such weapons may not have the time to appeal to the United Nations and may be compelled to use pre-emptive force to prevent an opponent from gaining an overwhelming military advantage.

However, the controversy over the need to modify the right to selfdefence is not exclusive to international law. The equivalent of such a debate has also been conducted in domestic criminal law particularly within the context of the battered woman's self-defence claims raised in nonconfrontational settings. On behalf of the "battered woman," some scholars, in particular feminist commentators, have challenged the non-responsiveness of the self-defence doctrine in domestic violence cases. These scholars, as shown below, have questioned the patriarchal construction of the self-defence discourse and opposed the rigid application of the temporal (imminence) requirement in cases where victims of domestic abuse employ fatal force against their abusers when the anticipated threat is not imminent. According to this school of thought, the requirement of imminence is merely a "translator" or "proxy" for the concept of necessity, which should, therefore, be discarded from the traditional contours of the self-defence doctrine. ${ }^{6}$

This article examines the bounds of self-defence through the domestic analogy, where the imminence rule is analyzed within the context of battered women's and the Bush Administration's claims. An analogy is drawn with the domestic context not only because there exist considerable similarities between the rights and duties of national and international persons in the theory of aggression and self-defence, but also because national law has a rich jurisprudence on self-defence with significant lessons and insight to offer to the analogous debate in international law. Admittedly, arguments produced at the domestic and international level were meant to address different scenarios, yet

4. U.N. Charter art. 51.

5. The White House, The National Security StRategy of the United States of AMERICA 15 (2002), available at http://www.whitehouse.gov/nsc/nss.pdf [hereinafter THE WHITE HOUSE].

6. See Onder Bakircioglu, The Contours of the Right to Self-Defence: Is the Requirement of Imminence Merely a Translator for the Concept of Necessity? 72 J. CRIM. L. $131,156-59$ (2008). 
the striking closeness of the logic and reasoning behind the attempt to alter the doctrine of self-defence gave the present author the impetus to study the doctrine of self-defence from a wider and comparative perspective. It must be noted that this study does not blindly deny the relevant differences of interstate and interpersonal relations. A comparative analysis of the self-defence doctrine must naturally take such differences into account.

This article will attempt to demonstrate that the requirement of imminence underlines the political character of the self-defence doctrine wherein private force may only be resorted to in the absence of institutional protection. The study will further show that the imminence rule can not merely be regarded as a "proxy" for establishing necessity; rather the elements of imminence, necessity and proportionality are inextricably connected to ensure that private force is only resorted to when national or international authorities are not in a position to prevent an illegal aggression, and that the defensive lethal force is not invoked for ulterior motives.

\section{NATIONAL SELF-DEFENCE AND THE DOMESTIC ANALOGY}

The relationship between national and international law has long been the subject of controversy among legal scholars. There are two essential theories, along with a number of various interpretations, explaining the nexus between international and domestic law. The first position, the monist view, proposes a unitary perception of the law according to which both national and international law form part of a single legal order. ${ }^{7}$ The roots of this doctrine emanate from Kantian philosophy which favours a unitary conception of law. This view advocates the supremacy of the law as opposed to the concept of unlimited sovereign prerogative: the idea of law to which jurisdictional reference must be made is not dependent on the sovereign, but is determinative of its own limits. ${ }^{8}$ The most radical form of monist theory was formulated by the influential Austrian jurist Hans Kelsen, who rejected any absolute borderline between national and international law. To him, norms that have the character of international law may possess national law qualities, and vice versa. The difference between these two bodies of law is merely a relative one; that is, while "[n]ational law is a relatively centralized legal order," international law has a relatively decentralized legal order. ${ }^{9}$ Kelsen argues that international law is not independent of the national legal order, for norms of international law could only be valid if they have become parts of national legal order through recognition by national authorities. "If," he argues, "their ultimate reason of

7. See PETER MALANCZUK, AKEHURST's MODERn INTRODUCTION TO INTERNATIONALLAW 63 (Routledge 7th ed. 1997) (1970).

8. Daniel P. O'Connell, The Relationship Between International Law and Municipal Law 48 GEO. L.J. 431, 432-33 (1960).

9. Hans Kelsen, General Theory ofLaw and State 325 (Anders Wedberg trans., The Lawbook Exchange 1999) (1945). 
validity is the presupposed basic norm of this legal order, then the unity of international law and national law is established, not on the basis of the primacy of the international legal order, but on the basis of the primacy of the national legal order." 10 Yet, this hypothesis does not address the status of customary international norms that are not recognized or are violated by certain states. These non-recognized or violated norms of international law will, in principle, continue to exist independently of the domestic legal norms of such states. ${ }^{11}$ In his later work, however, Kelsen recognizes the supremacy of international law over domestic law. He regards " $[t]$ he conflict between an established norm of international law and one of national law [as] a conflict between a higher and a lower norm."12 The monist conviction of the primacy of international law is partly related to the practical concern to overcome the assumption that international system is anarchic where each state may decline to be bound by its international obligations whenever national interests so require. ${ }^{13}$

The second school of thought, known as the dualist view, treats international law as completely independent of national law. These two branches of law are perceived to be regulating two mutually exclusive sets of relations that completely differ from one another in content. In Oppenheim's language, "[i]nternational and [m] unicipal law are in fact two totally and essentially different bodies of law which have nothing in common except that they are both branches - but separate branches - of the tree of law."14 The dualist approach, therefore, does not dwell upon the notions of conflict or rivalry, neither of superiority or subordination of one system over the other. ${ }^{15}$

Despite the heated controversy over the nature of the relationship between international and national law, no widely recognized consensus has emerged among scholars. ${ }^{16}$ The dualists are right in their contention that the

10. HANS KelSEn, PURE TheORY of LAW 335 (Max Knight trans., University of California Press 1967) (1934).

11. As Finch rightly argues, "[w]hen a general rule of customary international law is invoked against a state, it is not necessary that the state in question shall have assented to the rule either diplomatically or by having acted on it. It is enough to show that the general consensus of opinion within the limits of civilization is in favour of the rule." GEORGE A. FinCH, THE SOURCES OF MODERN INTERNATIONAL LAW 48 (William S. Hein \& Co., Inc. 2000) (1937).

12. Hans Kelsen, Principles of International law 421 (1952). See also MalanczuK, supra note 7, at 63 .

13. See Edwin Borchard, The Relation Between Intemational Law and Municipal Law, 27 VA. L. REV. 137, 142 (1940).

14. L. Oppenheim, Introduction to CYRIL M. Picciotto, The RELATION OF INTERNATIONAL LAW TO THE LAW OF ENGLAND AND THE UNITED STATES OF AMERICA 10 (1915).

15. J. Walter Jones, The 'Pure' Theory of International Law, 16 BRIT. Y.B. INT'L L. 5, 5 (1935).

16. Gerald Fitzmaurice, in his Hague Academy Lectures in 1957, noted that "the entire monist-dualist controversy is unreal, artificial and strictly beside the point." Ilmar Tammelo, Relations Between the International Legal Order and the Municipal Legal Orders - A "Perspectivist" View, AusTRALIAN Y.B. INT'L L. 211 , 211 (1967) (quoting Gerald Fitzmaurice, The General Principles of International Law Considered from the Standpoint of the Rule of 
sources of international law differ from those of national law: while domestic law is a product of law-enacting and law-determining branches of national authorities, international law emerges from customs and law-making treaties in the international sphere. ${ }^{17}$ It is also true that they differ with respect to the relations they govern: domestic law regulates relations between individuals under the sway of a centralized state and the relations between the state and the individual. By contrast, international law in principle governs relations among states. National law and the law of nations further differ in hierarchical terms; that is, while the former involves the law of a sovereign over individuals subjected to its authority, the latter regulates the relations of theoretically equal sovereigns. $^{18}$

These schools of thought, however, appear to adapt a mutually exclusive approach and thus overlook the overlapping qualities of the two systems. It must be remembered that not until the $17^{\text {th }}$ century was there any specific legal formulation exclusively applicable to international relations. The legal inauguration of the modern state system and the actual foundation of international law were essentially laid with the Treaty of Westphalia of 1638, which ended the religious wars within Europe and established a secular system of territorial authority. In other words, international law was effectively midwived in the $17^{\text {th }}$ century as the natural law doctrine gradually lost its supremacy in favour of positive law. ${ }^{19}$ Thus, only after the secularization of natural law thinking was the law of nations believed to have a unique character qualitatively different from the law governing interpersonal relations. The source of this new body of law, according to Grotius, was not divine; in contrast, it had received its obligatory force "from the will of nations."

Furthermore, the just war tradition was profoundly affected by the principles of domestic criminal law. Indeed, ideas about the legitimate resort to lethal force first emerged over the debate whether Christians could lawfully perform military service for the imperial Roman army, which inevitably involved the practice of deadly force as opposed to the pacifistic philosophy of early Christianity. ${ }^{21}$ The just war doctrine attempted to affirm that under

Law, 92 Hague Recuell 70, 71 (1957-II)). See also Adolphus G. Karibi-Whyte, The Twin Ad Hoc Tribunals and Primacy Over National Courts, 9 CRIM. L.F. 55, 70 (1999).

17 See FinCH, supra note 11, at 59.

18. See L. OPPENHEIM, INTERNATIONAL LAW: A TREATISE 37 (H. Lauterpacht ed., Longmans, Green and Co., 8th ed. 1955).

19. Natural law sought the binding authority of the law in some source other than sovereignty, such as in nature, reason, or religious and moral values. See David Kennedy, International Law and the Nineteenth Century: History of an Illusion, 17 QUINNIPIAC L. REv. 99, (1997).

20. Hugo Grotius, The LaW of War and Peace 44 (Francis W. Kelsey trans., 1925) (1625), available at http://www.lonang.com/exlibris/grotius/gro-100.htm. From this perspective, positivist understanding rooted the binding force of international law in the consent of sovereign nations, an analogy based on the private law of contract. See Kennedy, supra note 19, at 113; Anthony Carty, Critical International Law: Recent Trends in the Theory of International Law, 2 EUR. J. INT'L L. 66, 73 (1991).

21. See Mohammad Taghi Karoubi, Just OR UnJust War? InTERnational LaW and 
extreme circumstances a Christian could shed blood for his country, insofar as this was executed with love, restraint and with the pure intention to punish the sinful. The major evil did not lie in war itself, but in the love of cruelty, violence, greed and the lust for rule and vengeance. ${ }^{22}$ This philosophy was later extrapolated, with little modification, to the inter-state level, where states, similar to private persons, could wage war for purportedly noble purposes, such as punishing the wicked, enforcing the law, or self-defence, rather than for oppression or the acquisition of territory. ${ }^{23}$

Grotius, in this respect, after enumerating the conditions for a rightful exercise of private self-defence, notes that "[w] hat has been said by us up to this point, concerning the right to defend oneself and one's possessions, applies chiefly, of course, to private war; yet it may be made applicable also to public war, if the difference in conditions be taken into account." ${ }^{24}$ Vattel was of the same opinion: "Every nation," he wrote, "as well as every man, has ... a right to prevent other nations from obstructing her preservation, her perfection, and happiness, - that is, to preserve herself from all injuries ...."25 The contemporary American political philosopher Walzer also argues that the comparison of international to civil order is of extreme importance for the theory of aggression. "Every reference to aggression," he writes, "as the international equivalent of armed robbery or murder, and every comparison of home and country or of personal liberty and political independence, relies upon what is called the domestic analogy. Our primary perceptions and judgments of aggression are the products of analogical reasoning." ${ }^{26}$ Indeed, international law was founded upon one of the main premises that there exists a direct connection and analogy between the rights and duties of natural and international persons. The early structure and main pillars of international society were thus based on such a reasoning, which justified wholesale borrowing from the Roman ius gentium and many other concepts, principles, and rules from diverse systems of municipal law. In other words, domestic analogy has constantly been invoked since the law of nations acquired political significance to regulate international relations. "An examination of the writings of the great publicists," announces Dickinson, "particularly those of the seventeenth and eighteenth centuries, reveals something of the extent to which

UNILATERAL USE OF ARMED FORCE BY STATES AT THE TURN OF THE 20TH CENTURY 29-30 (2004); see also CHRISTIANITY AND PAGANISM: THE CONVERSION OF WESTERN EUROPE 350-70 (J.N. Hilgarth ed., University of Pennsylvania Press 1986) (1969).

22. See SAINT Augustine, THE CitY of God 693-94 (Marcus Dods trans., Random House Inc. 1950); Thomas AQuinas, Summa Theologiae 83-85 (Thomas R. Heath O.P. trans., London Blackfriars vol. 351972); FREDERICK HOOKER RUSSELL, THE JUST WAR IN THE MIDDLE AGEs 16 (Cambridge University Press 3d ed. 1975).

23. See Stephen C Neff, A Short History of International Law, in INTERNATIONAL LAw 33 (Oxford University Press $2 d$ ed. 2006).

24. GROTIUS, supra note 20, at bk. II/I/XVI.

25. Monsieur De Vattel, The Law of Nations, (Philadelphia: T. \& J. W. Johnson \& Co., 1883), at bk. ПI/IV/XLIX.

26. Michael Walzer, Just and UnJUSt Wars: A MORAL ARguMENT With Historical ILLUSTRATIONS 58 (Basic Books 3d ed. 2000) (1977). 
we are indebted to this analogy for almost everything that is regarded as fundamental in modern international law." 27

Nevertheless, it is not the focus of this study to examine the role of municipal law in the construction of the international legal system. Neither does the study suggest that domestic analogy offers an entirely accurate depiction of international society. As Walzer writes, "[s]tates are not in fact like individuals (because they are collections of individuals) and the relations among states are not like the private dealings of men and women (because they are not framed in the same way by authoritative law)." ${ }^{28}$ A resort to domestic analogy, nonetheless, has been made for a better understanding of the selfdefence doctrine. Therefore, despite the controversial status of such an analogy in the study of international relations, ${ }^{29}$ this study employs domestic analogy as a practical tool to analyze the role, rationale and objectives of the right of selfdefence with a view to questioning whether the requirement of imminence should be discarded from the traditional self-defence doctrine in national and international law.

\section{THE TEMPORAL REQUIREMENT OF SELF-DEFENCE IN MUNICIPAL AND INTERNATIONAL LAW}

Under the U.N. system, the regulation of force can be said to dramatically parallel that of its domestic counterpart. Particularly over the course of the last century, international law made significant advances toward the notion of centrality and abandoned its primarily customary character in favour of more systematic and clear-cut treaty rules. ${ }^{30}$ This is essentially noticeable with respect to the regulation of armed aggression in the U.N. Charter where (1) the use of armed force is strictly prohibited; (2) the Security Council is designated as a central authority, which holds a monopoly on the lawful use of force; and (3) national self-defence is only permitted when the Security Council is unable to provide protection against an illegal attack. ${ }^{31}$ Furthermore, defensive lethal

27. Edwin DeWitt Dickinson, The Analogy Between Natural Persons and International Persons in the Law of Nations, 26 YALE L.J. 564, 564 (1917).

28. WALZER, supra note 26, at 72.

29. Many international lawyers, particularly those of the late 19th and early 20th century, rejected the domestic analogy because they deemed international law sui generis. They mainly argued that whether or not international law is primitive or defective cannot be determined by reference to the standards of municipal law, for international law exists independently of municipal law. See Hidemi Suganami, The Domestic ANALOgY and World Order Proposals 9-10 (Steve Smith et al. eds., Cambridge University Press 1989); MALANCZUK, supra note 7, at 63. Today some modern scholars argue that "rules derived from the criminal law are ill-suited for interactions between nation-states in an international system characterized by anarchy." John Yoo, Using Force, 71 U. CH. L. REv. 729, 732 (2004).

30. Nico Krisch, More Equal than the Rest? Hierarchy, Equality and U.S. Predominance in International Law, in UNITED STATES HEGEMONY AND THE FOUNDATIONS OF INTERNATIONAL LAW 135, 150 (Michael Byers \& Georg Nolte eds., Cambridge University Press 2003).

31. See DAVID Rodin, WAR AND SElF-DefEnce 107 (2002). The reliance on the domestic 
force has been restricted by the elements of "imminence," "necessity" and "proportionality" both at the international level.

Likewise, both domestic and international law prohibit measures of self help; instead, legal entities must rely on the central bodies to act on their behalf. At the national level, individuals are forbidden to assert their rights through force, because the state, with its monopolistic and legitimate coercive machinery, is designed as an objective body to secure rights and establish order. $^{32}$ However, in extreme circumstances, individuals may exercise their right of self-preservation, particularly when their survival, physical integrity or liberty is threatened by unlawful aggression. ${ }^{33}$ Similarly, despite its relatively decentralized structure, under the current frame of international law, the use of armed force is unlawful unless it is authorized by the Security Council or fits the legal paradigm of self-defence. In other words, national self-defence is the sole justified unilateral armed aggression that is permitted without the Security Council's mandate.

Nevertheless, the legality of self-defence is dependent upon the satisfaction of certain conditions. Namely, that the defendant must reasonably believe that there is a "present" or "imminent" danger of armed aggression and that the use of lethal force is absolutely "necessary" and "proportionate" to ward off this illegal threat. ${ }^{34}$ If lethal force was considered to be the only alternative to avoid an unlawful attack, the putative defender must show ${ }^{35}$ that the threat was severe and imminent and that the use of force was proportionate and necessary. Both in national and international law, necessity demands that the defendant had no less harmful alternative to prevent the attack, no chance of retreat (if this is required by the national system), ${ }^{36}$ or recourse to the relevant

analogy in the establishment of the U.N. charter was vividly expressed by President Franklin Roosevelt in his speech in the Foreign Policy Association in 1944: "Peace, like war, can succeed only where there is a will to enforce it, and where there is available power to enforce it. The Council of the United Nations must have the power to act quickly and decisively to keep the peace by force, if necessary. A policeman would not be a very effective policeman if, when he saw a felon break into a house, he had to go to the Town Hall and call a town meeting to issue a warrant before the felon could be arrested." U.S. President Franklin D. Roosevelt, Radio Address at a Dinner of the Foreign Policy Association (Oct. 21, 1944), available at: http://www.presidency.ucsb.edu/ws/index.php?pid=16456; SUGANAMI, supra note 29, at 121.

32. See MaX Weber, From MaX Weber: Essays IN Sociology 178 (H.H. Gerth \& C. Wright Mills eds. \& trans., Routledge 1991) (1948).

33. See Suzanne Uniacke, Self-Defense and Natural Law, 36 AM. J. JURIS. 73, 73-74 (1991).

34. See RoDIN, supra note 33, at 107-08; Michael Skopets, Battered Nation Syndrome: Relaxing the Imminence Requirement of Self-Defense in International Law, 55 AM. U. L. REV. 753, 760 (2006).

35. However, in criminal law, the defender does not have to prove anything in order to be granted a jury instruction on self-defense, which is in line with the presumption of innocence. As Dressler notes, "[a] defendant is entitled to an instruction on a defence if he presents some credible evidence in support of the claim." JOSHUA DRESSLER, UNDERSTANDING CRIMINAL LAW 241 (Bender \& Company 3d ed. 2001).

36. It is important to note that most jurisdictions do not impose a retreat requirement on the putative defender before his exercise of lethal force. See ROBERT F. SCHOPP, JUSTIFCATION Defenses AND Just Convictions 91 (Jules Coleman ed., Cambridge University Press 1998); 
national or international authorities. ${ }^{37}$ Proportionality requires the balancing of the interests of both the aggressor and the defender. Therefore, the use of defensive force must not be excessive or disproportionate to the harm threatened by the illegal attack. ${ }^{38}$

The requirement of imminence, on the other hand, signifies the temporal facet of self-defence. Traditionally, pleas of self-defence are only accepted when the lethal response of the defendant is immediate, directly following the untoward threats or acts of the aggressor. A time lag between the illegal threat or act and the response usually undermines the validity of self-defence claims. ${ }^{39}$ As Fletcher notes:

The requirement of imminence means that the time for the use of force will brook no delay. The defender cannot wait any longer. This requirement distinguishes self-defence from the illegal use of force in two temporally related ways. A preemptive strike against a feared aggressor is illegal force used too soon; and retaliation against a successful aggressor is illegal force used too late. Legitimate self-defence must be neither too soon nor too late. ${ }^{40}$

The requirement of imminence plays a critical role in assessing the seriousness of the threat, the proportionality of the lethal response, the availability of legal alternatives and the real motive of the defender. ${ }^{41}$ Therefore, pre-emptive strikes, as a matter of principle, are illegal in international law and in domestic legal systems. Such pre-emptive strikes, as Fletcher observes, "are illegal because they are not based on a visible manifestation of aggression; they are grounded in a prediction of how the feared enemy is likely to behave in the future." ${ }^{, 2}$ However, as noted above, the temporal requirement has been subject

Mitchell N. Berman, Justification and Excuse, Law and Morality, 53 DUKE L.J. 1, 13-14 (2003); Catherine L. Carpenter, Of the Enemy, Within the Castle Doctrine, and Self-Defense, 86 MARQ. L. REV. 653, 664 (2003).

37. See James Slater, Making Sense of Self-Defence, 5 NotTingham L.J. 140, 142 (1996).

38. See George P. FleTCHER, Basic CONCEPTS OF CRIMINAL LAW 135 (1998).

39. See BELINDA MoRrissey, When WOMEN KILL: Questions of AGENCY AND SubJeCtivity 73 (Maureen McNeil et al. eds., Routledge 2003).

40. FLETCHER, supra note 38, at 133-34.

41. Time has always been a touchstone for criminal law, particularly in the law of murder and self-defence. In many common law jurisdictions, time has essentially marked the difference between provoked homicide and first-degree murder. See V. F. Nourse, Self-Defense and Subjectivity, 68 U. CHI. L. Rev. 1235,1244 (2001).

42. FLETCHER, supra note 38 , at 134 . In this regard, acts preparatory to the use of defensive force should be treated similarly. This issue arose in Attorney General's Reference where it was held that the preparation of petrol bombs to protect oneself and one's property against an unlawful threat was not necessarily illegal. "The fact that in manufacturing and storing the petrol bombs the respondent committed offences [under the Explosives Act 1875 ... ] did not necessarily involve that when he made them his object in doing so was not lawful. The means by which he sought to fulfil that object were unlawful, but the fact that he could never without committing offences reach the point where he used them in self-defence did not render 
to challenge both at the international and national levels. The relevant claims raised by the proponents of the preventive war doctrine will now be examined.

\section{THE BUSH DOCTRINE: ARBITRARINESS WITHIN THE REALM OF FORCE}

Firstly, the implications of discarding the element of imminence appear to be much graver at the international level, because warfare, be it defensive or offensive, by its very nature results in the killing of large numbers of people, irrespective of age, sex, nationality or political belief. Unlike private killings, warfare often results in far-reaching destruction of human life, environment, culture, and property. Inevitably, it further causes the death of civilians and those who are not directly the sources of the illegal threats. Since one of the most important requirements of self-defence is that defensive lethal force must be directed to the source of danger, the non-discriminatory feature of warfare renders the tasks of preventing state aggression and clearly defining its exceptions more pressing.

This paper will attempt to illustrate that the Bush Doctrine went well beyond the confines of anticipatory self-defence, which, despite its controversial status, might satisfy the requirements of Article 51 of the U.N. Charter. ${ }^{43}$ The Bush Administration's "preventive war" doctrine is essentially based upon contingencies and fear, where war may be launched against an incipient threat, which, if permitted to fully form, could purportedly be neutralized at a much higher cost. ${ }^{44}$ In this respect, the Bush Doctrine appears to attempt to revive the positivist conception of warfare, where armed hostilities were simply regarded as being beyond the realm of law in inter-state relations, characterized by marked decentralization and anarchy. ${ }^{45}$ As is well-known, in

his object in making them for that purpose unlawful. The object or purpose or end for which the petrol bombs were made was not itself rendered unlawful by the fact that it could not be fulfilled except by unlawful means." Michael J. ALLEN, TeXTBOoK ON CRIMINAL LAW 200 (Oxford University Press 2007) (quoting Attorney General's Reference (No. 2 of 1983) [1984] Q.B. 456, 470 (C.A.)). However, if the defendant has the opportunity to resort to the state authorities against the illegal threat he faces or has the chance to contain the threat with non-violent means, he is not entitled to make illegal preparations to defend himself. It can therefore be argued that the legality of preparations is dependent upon the legality of the defensive force, which should only be invoked as a last resort. Having stated that, extreme cases may emerge wherein the defendant has to carry weapons (if, for instance, he is incessantly being followed by his enemies and the police cannot provide him constant protection) for his self-protection. See id. at 200-01. In Evans v. Hughes, the Divisional Court noted that the possession of a metal bar in a public place could only be justified by showing that there was an imminent threat affecting the particular circumstances in which the weapon was carried. Evans v. Hughes, (1975) 1 W.L.R 1452 (Q.B). For more information see ALLEN, supra note 42, at 200-01.

43. See Oscar Schachter, The Right of States to Use Armed Force, 82 Mich. L. REv. 1620, 1635 (1984).

44. See Michael Cox, Empire? The Bush Doctrine and the Lessons of History, in AMERICAN POWER IN THE 21 sT CENTURY 22-23 (Davis Held \& Mathias Koenig-Archibugi eds., 2004); Donald R. Rothwell, Anticipatory Self-Defence in the Age of International Terrorism, 24 U. QUEENSLAND L.J. 337, 338 (2005).

45. Sharon Korman, The Right of Conquest: THE ACQuisition of Territory by FORCE IN INTERNATIONAL LAW AND PRACTICE 7-8 (1996). 
the positivist era, because states used armed force for the implementation of their national policies and in furtherance of their political interests, the concept of self-defence lost its significance. ${ }^{46}$ However, following the horrific consequences of the World Wars, not only was the sovereign era's unqualified right of warfare abolished,$^{47}$ but traditional just war reasons, ${ }^{48}$ including the recovery of property, securing redress for wrongdoings, and avenging injuries, were reduced to the right of self-defence under the U.N. Charter. The U.N. Charter, in this regard, has been the most important legal tool in restricting the legitimacy of "unilateral use of force" to the single case of self-defence. National-defence, therefore, has become today's sole casus belli in the absence of Security Council authorization for the use of force. ${ }^{49}$

Under the U.N. collective security system, Member States are now obliged to settle their disputes through peaceful means and refrain not only from the use of force, but also from the threat of force in their international relations. The general prohibition on the use of force, as stipulated under Article 2(4), constitutes a peremptory norm of international law, from which Members cannot derogate. ${ }^{50}$ The Charter reserves to the Security Council the full authority to use military force. Indeed, under Article 2(4), the Security Council is conferred with the primary responsibility for the maintenance of international peace and security and the competence to enjoy a monopoly on the use of force to this end. Furthermore, Article 2(5) expressly provides that "[a]ll

46. Josef L. Kunz, Individual and Collective Self-Defense in Article 51 of the Charter of the United Nations, 41 AM. J. INT'L L. 872, 875-76 (1947).

47. See Stanimir A. Alexandrov, Self-Defense Against the Use of Force IN INTERNATIONAL LAW 19-27 (1996); STEPHEN C. NEFF, WAR AND THE LAW OF NATIONS: A GENERAL HISTORY 168-70 (2005).

48. Just war tradition provided guidelines as to when and how to engage in warfare, which initially emerged as an attempt to provide a theoretical basis to make war religiously possible and endeavoured to introduce morality within warfare. Yet such moral principles did little to prevent or restrict warfare; rather they were ignored as the practical considerations overshadowed morality. "Even in its heyday," notes Dinstein, "the 'just war' doctrine was mostly a convenient tool or fig-leaf, and states went to war whenever they deemed fit, using or abusing an arbitrary list of just causes." Yoram Dinstein, Comments on War, 27 HARV. J. L. \& PUB. POL'Y 877, 877 (2004).

49. Although, the notion of humanitarian intervention, an unauthorized coercive action undertaken on humanitarian grounds, has been posited to be a legitimate use force that is compatible with Article 2(4) of the U.N. Charter, this reading of the Charter is not technically correct. Dinstein notes that "[n]o individual state (or group of states) is authorized to act unilaterally, in the domain of human rights or in any other sphere, as if it were the policemen of the world. Pursuant to the Charter, the Security Council - and the Security Council alone - is legally competent to undertake or to authorize forcible 'humanitarian' intervention." See YORAM DINSTEIN, WAR, AGGRESSION AND SELF-DEFENCE 90-91 (Cambridge University Press 4th ed. 2005) (1988); cf. Julie Mertus, Reconsidering the Legality of Humanitarian Intervention: Lessons from Kosovo, 41 WM. \& MARY L. REV. 1743, 1750-51 (2000); Emily Schroeder, The Kosovo Crisis: Humanitarian Imperative Versus Intemational Law, 28 FLETCHER F. WORLD. AFF. 178, 181 (2004).

50. Military and Paramilitary Activities (Nicar. v. U.S.), 1986 I.C.J. 14, paras. 187-01 (June 27). 
Members shall give the United Nations every assistance in any action it takes in accordance with the present Charter, and shall refrain from giving assistance to any state against which the United Nations is taking preventive or enforcement action." 51 The U.N. Charter has thus created a whole set of legal norms regarding the legitimate use of force. Today, therefore, the religious or moral justness of a given conflict is not relevant to an assessment of whether the use of force is compatible with the collective security system under the U.N. Charter. $^{52}$

The preventive war doctrine, however, claims entitlement to employ high levels of unilateral force to arrest an incipient development that is not yet operational or threatening, but that if permitted to mature, could purportedly be neutralized only at a higher cost. Preventive war thus differs from anticipatory self-defence in that the latter can only be waged against a tangible and imminent danger, which might therefore fit the legal framework of Article 51. ${ }^{53}$

The rationale of the preventive war doctrine is grounded upon the assumed irrationality of relying on the U.S. Cold War strategies of deterrence and containment, which have been deemed ineffective particularly against "shadowy terrorist networks" in a post-September 11 world. ${ }^{54}$ Although the United States had been following a pattern of favoring American values and interests over adherence to international norms, what changed dramatically after the September 11 attacks was the assertion that America had confronted a state of emergency that could only be eliminated with a robust, unilateral approach to eventually uproot terrorism. ${ }^{55}$ In this context, the spatial and temporal limit of the so-called "war on terror" ${ }^{156}$ has been left uncertain. It was announced that "[t]he war against terrorists of global reach is a global enterprise of uncertain duration., ${ }^{, 57}$ This new approach stands in stark contrast to traditional warfare that is characterized by definite spatial and temporal boundaries. Indeed, as Hardt and Negri note:

The old-fashioned war against a nation-state was clearly

51. U.N. Charter art. 2, para. 5 .

52. Dinstein, supra note 48 , at 880 .

53. See generally W. Michael Reisman \& Andrea Armstrong, The Past and Future of the Claim of Preemptive Self-Defense, 100 AM. J. INT'L L. 525,538-46 (2006).

54. George W. Bush, President of U.S., Prevent Our Enemies from Threatening Us, Our Allies and Our Friends with Weapons of Mass Destruction (June 1, 2002), available at http://www.whitehouse.gov/nsc/nss5.html.

55. Gerry Simpson \& Nicholas J. Wheeler, Pre-emption and Exception: International Law and the Revolutionary Power, in INTERNATIONAL LAW AND INTERNATIONAL RELATIONS: BRIDGING THEORY AND PRACTICE 120 (Thomas J. Biersteker et al. eds., 2007).

56. See Katharine Q. Seelye \& Elisabeth Bumiller, After the Attacks: The President: Bush Labels Aerial Terrorist Attacks 'Acts of War,' N.Y. TIMES, Sept. 13, 2001, at A16; Interview by ABC News with Colin L. Powell, U.S. Sec'y of State (Sept. 12, 2001), available at http://www.globalsecurity.org/military/library.news.2001.09.mil-0109120usia10.htm.

57. See The White House, The Information Warfare Site, http://www.iwar.org.uk/military/resources/nss-2002/nssintro.htm (last visited Oct. 5, 2008). 
defined spatially, even if it could at times spread to other countries, and the end of such a war was generally marked by the surrender, victory, or truce between the conflicting states. By contrast, war against a concept or set of practices, somewhat like a war of religion, has no definite spatial and temporal boundaries. Such wars can potentially extend anywhere for any period of time. ${ }^{58}$

The Bush Doctrine rationalizes such a perpetual state of war on the premise that the existing international legal frame is inadequate to meet the demands of modern threats posed by "terrorists" and "rogue states," and that the United States' unilateralism is necessary to counter such threats in a world characterized by a Hobessian state of nature. ${ }^{59}$

The apologists of the Bush Doctrine attempt to discard the imminence rule by indicating that modern technology is capable of causing unparalleled damage and loss of human life. In other words, it is argued that modern weaponry (including nuclear, biological and chemical weapons) poses an unprecedented threat to the world security. Such weapons are portable, relatively easy to make, cheap to produce, and therefore are perfect weapons for "rogue states" and "terrorists." Consequently, "if necessity can be demonstrated before the attack, then a nation should not be required to wait to be attacked before it can defend itself, especially if the first blow is potentially devastating."60 The 2002 National Security Statement declares that such an intention to undertake preventive military action protects American interests even against impalpable threats: ${ }^{61}$

The United States has long maintained the option of preemptive actions to counter a sufficient threat to our national security. The greater the threat, the greater is the risk of inaction - and the more compelling the case for taking anticipatory action to defend ourselves, even if uncertainty remains as to the time and place of the enemy's attack. To forestall or prevent such hostile acts by our adversaries, the United States will, if necessary, act pre-emptively. ${ }^{62}$

58. Michael HaRdT \& ANTONio NEGRi, Multitude: WAR AND DEMOCARCY IN THE AGE OF EMPIRE 14 (2004) (emphasis added).

59. See Michael Hirsh, Bush and the World, 81 ForeIGN AFF. 5, 39-40 (2002); Robert Kagan, Power and Weakness, 113 POL'Y REV. 3, 3 (2002).

60. See Mark L. Rockefeller, The "Imminent Threat" Requirement for the Use of Preemptive Military Force: Is it Time for a Non-Temporal Standard?, 33 DENV. J. INT'L L. \& POL'y 131,139 (2004).

61. See Jorge Alberto Ramírez, Iraq War: Anticipatory Self-Defense or Unlawful Unilateralism?, 34 CAL. W. INT'L L.J. 1, 3 (2003).

62. THE WHITE HouSE, supra note 5, at 15. 
Hence, it was made clear that America would not solely rely on a reactive posture because of the alleged difficulty of deterring potential dangers posed by the "terrorists" or "rogues," and by the magnitude of harm that could occur from their possible use of weapons of mass destruction (WMD). This approach clearly expands the traditional scope of Article 51, which requires the occurrence of an armed attack before the right to self-defence may be invoked. Yet, it also reaches well beyond the bounds of the controversial notion of anticipatory self-defence that finds its classical formulation in the Caroline case, according to which the necessity for anticipatory self-defence must be "instant" and "overwhelming," "leaving no choice of means" and "no moment for deliberation." 63

The Bush Doctrine presents the existence of "terrorist groups" and "rogue states," armed with "modern weaponry," as the primary reason for the United States' opposition to the traditional bounds of the self-defence doctrine. This approach, however, essentially reiterates the main premises of the realist school, which presumes that in a decentralized, anarchic international society, where there is no global police force or compulsory jurisdiction, self-help remains critical for state conduct. Therefore, armed force may not only be used in cases of self-defence, but also for the vindication of rights, correction of unjust wrongs, and for humanitarian reasons. ${ }^{64}$ In fact, the United States has long been one of the few states that presses for a broader reading of exceptions to the general prohibition on the use of force. The United States has sought to include the protection of nationals abroad, humanitarian intervention, responses to terrorism, and anticipatory use of force within the traditional matrix of selfdefence. Since the 1990s, the United States has further claimed a right to forcefully implement Security Council resolutions that evidently did not contain authorizations for the use of military force. ${ }^{65}$

The United States' attempt to relax the strict limits on the use of force presents serious challenges to the collective security system, for other states

63. See Daniel Webster, Letter from U.S. Secretary of State Daniel Webster to British Minister Henry Fox (24 April 1841), 29 BRIT. \& FOR. ST. PAPERS 1137 (1841).

64. See Edward Hallett Carr, The Twenty Years' Crisis, 1919-1939: AN INTRODUCTION TO THE STUDY OF INTERNATIONAL RELATIONS 86-88 (Harper \& Row 1946) (1939); ChRistopher C. Joyner, INTERNATIONAL LAW IN THE 21ST CENTURY: RULES FOR Global Governance 167 (Deborah J. Gemer \& Eric Selbin eds., 2005); OSCAR SCHACHTER, International Law in Theory and Practice 136 (1991); Principles and Problems of International Politics: Selected Readings 33 (Hans J. Morgenthau \& Kenneth W. Thompson eds., 1950).

65. See Krisch, supra note 30 , at 148. The Bush Administration and its allies, before resorting to the preventive war doctrine, sought a Security Council Resolution explicitly authorizing the use of force against Iraq. Yet as the Council denied such an authorization, the allied forces argued that the war was legal under prior Security Council Resolutions 678 and 687. See S.C. Res. 678, II 2, U.N. Doc. S/Res/678 (Nov. 29, 1990); S.C. Res. 687, qII 14, 29 , 34, U.N. Doc. S/Res/687 (Apr. 3, 1991). The international community did not accept the validity of this claim simply because these resolutions were passed within the context of Kuwaiti liberation in 1991. 
might also employ a similar logic and wage wars of aggression under the pretext of self-defence or humanitarian intervention. As the North Korean foreign ministry threateningly underlined, "[p]re-emptive attacks are not the exclusive right of the US." ${ }^{66}$ Indeed, once the legitimacy of preventive wars is accepted then states may legitimately commence hostilities against one another, particularly when the latter's past practices or hostile intentions suggest that in an indefinite future it might conceivably pose a threat to the former's political independence or territorial integrity.

Since the preventive war doctrine does not require the perceived threat to be material, imminent, or overwhelming, it inevitably grants full discretion to states as to whether and when a putative aggressor constitutes a potential threat to their security. Of course, as highlighted in the case of Nicaragua, "it is the state which is the victim of an armed attack which must form and declare the view that it has been so attacked.". ${ }^{67}$ Nevertheless, in the absence of an actual armed attack or pending danger, any calculation of inevitability is doomed to be speculative and presumptive, which would eventually serve the interests of militarily superior countries. ${ }^{68}$ The United States currently enjoys the strongest economic and military capacity in the world, and may accordingly adopt exceptional measures other states cannot afford. America could also use its privileged position in the Security Council to prevent other states from using force, as it has done many times during the Cold War years and in the 1990s. ${ }^{69}$

In summary, the Bush Doctrine takes the already controversial concept of anticipatory self-defence a step further into the murky realm of subjectivity that may justify military venturism "from the Korean peninsula to the Taiwan straits, to Kashmir and beyond." ${ }^{70}$ Therefore, it attempts to modify the current law of self-defence by envisioning a general licence for the use of force in cases where a state believes that a putative aggressor possesses or develops WMD, and thus might pose a possible future threat to its own security. The elimination of the imminence rule, however, would not only discard the authority of the Security Council, but might also trigger many unwarranted

66. Jonathan Watts, $N$. Korea Threatens US with First Strike, THE GuARdian, Feb. 6, 2003, available at http://www.guardian.co.uk/world.2003/fed/06/usa.northkorea.

67. Military and Paramilitary Activities, supra note 50, at II 195 (emphasis added).

68. See ANTONY ANGHIE, IMPERIALISM, SOVEREIGNTY AND THE MAKING OF INTERNATIONAL LAw 227 (James Crawford \& John S. Bell, eds., 2004); JoYNER, supra note 64, at 170. The danger of granting exclusive authority to states to judge the necessity of defensive force was clearly underlined by the Nuremberg Tribunal as Germany claimed self-defence in the events leading to World War II. The court concluded that the nature of any action taken under the claim of self-defence "must ultimately be subject to investigation or adjudication if international law is ever to be enforced." HuMPHREY WALDOCK, THE LAW OF NATIONS: AN INTRODUCTION TO THE INTERNATIONAL LAW OF PEACE 407 (1963); Oscar Schachter, Self-Defense and the Rule of Law, 83 AM. J. INT'L L. 259, 261-62 (1989).

69. See Thomas Schindlmayr, Obstructing the Security Council: The Use of Veto in the Twentieth Century, 3 J. Hist. INT'L L. 218, 233 (2001).

70. Miriam Sapiro, Iraq: The Shifting Sands of Preemptive Self-Defense, 97 AM. J. INT'L L. 599,599 (2003). 
conflicts under the flag of self-defence, because the Bush Doctrine does not define the circumstances in which a suspected threat might justify military action. ${ }^{71}$ As Schachter observes, "[t]o say that each state is free to decide for itself when and to what extent it may use arms would remove the principal ground for international censure, and, in effect, bring to the vanishing point the legal limits on unilateral recourse to force. ${ }^{, 72}$ Naturally, the necessity to retain the temporal requirement is tied to the legitimate concern that permissive opportunities to use unilateral force might invite abuse from powerful states, which, throughout history, have frequently sought to enhance their own national interests at the expense of weaker states and international order.

\section{RELAXING THE IMMINENCE RULE IN BATTERED WOMEN'S SELF-DEFENCE CLAIMS?}

As indicated above, the legal framework of self-defence is also sought to be modified by a feminist critique on the ground that the traditional contours of self-defence do not fit with a battered woman's experience in which the concepts of "imminence," "reasonableness," "proportionality," and "retreat" are comparatively less apparent and more case-specific. Since the 1970 s, some feminist commentators ${ }^{73}$ have underlined the subordination of women and sexist presumptions within the legal discourse that create inequalities for women in general and for battered women's self-defence claims in particular. These scholars principally posit that self-defence rules were established to exonerate a man who uses lethal force to defend himself or his family in the face of an unlawful attack posed by a man of similar size and strength with whom the defender usually had an isolated or single confrontation. ${ }^{74}$ Women

71. See Yoo, supra note 29 , at 735.

72. SCHACHTER, supra note 64 , at 263. Similarly, Franck rightly argues that: “[A] general relaxation of Article 51's prohibitions on unilateral war-making to permit unilateral recourse to force whenever a state feels potentially threatened could lead to . . . reductio ad absurdum. The law cannot have intended to leave every state free to resort to military force whenever it perceived itself grievously endangered by actions of another, for that would negate any role for law." ThOMAS M. FRANCK, RECOURSE TO FORCE: STATE ACTION AGAINST ThREATS AND ARMED ATTACKS 98 (2002).

73. Although there is no single feminist response to criminal law, criminal justice, and domestic violence issues, it can safely be argued that many feminists resist biased theories and highlight the significance of attentiveness to particularity and specific context. Indeed, many feminist scholars stress a larger pattern of inequalities that are based upon gender, race and class differences. Feminist approaches to domestic violence, to put it simply, focus on the rights of the victims of abuse and call for empathic responses to such women who risk criminal charges for committing untoward acts against their abusers. For an interesting discussion see Martha Minow, Between Vengeance and Forgiveness: Feminist Responses to Violent Injustice, in NanCy E. DowD \& Micheille S. JacobS, Feminist Legal Theory 384 (2003). However, it should be reiterated that this study is confined to analyse the feminist critique in a narrow sense, and restricts its scope to those scholars who challenge the strict application of the temporal rule in non-confrontational killings.

74. Cathryn Jo Rosen, The Excuse of Self-Defense: Correcting a Historical Accident on 
are thus gravely disadvantaged to fit into such a masculine paradigm of selfdefence, for they usually differ from an ordinary male defender in size, strength, socialization, defensive behaviour, etc. ${ }^{75}$ The requirements of private selfdefence, such as the imminence rule, consideration of the circumstances immediately surrounding the deadly defensive force, and the employment of an "objective reasonable man" standard, ${ }^{76}$ also weaken female defendants' claims. ${ }^{77}$ More importantly, women's experiences with constant domestic abuse were simply not envisioned when the legal bounds of self-defence were drawn. ${ }^{78}$

The main challenge, however, is directed at the strict temporal requirement. ${ }^{79}$ Firstly, it is important to note that, contrary to common belief, the majority of battered women kill their abusers in confrontational settings where the imminence rule does not pose any significant challenge to self-

Behalf of Battered Women Who Kill, 36 AM. U. L. REV. 11, 34 (1986).

75. Laurie J. Taylor, Provoked Reason in Men and Women: Heat-of-Passion Manslaughter and Imperfect Self-Defense, 33 UCLA L. REV. 1679,1701 (1986).

76. Taylor forcefully argues that there is no common law reference to the concept of a reasonable woman. "Rather than developing a separate standard for women, criminal law has held and continues to hold female defendants to a male standard of reasonableness. ... The historical development of the standard reveals its male bias, but the language of the standard reveals more. Linguistic theory has confirmed that women have been present in official language only as the 'other,' and experience proves that the use of male pronouns effectively excludes a woman's perspective and experience. In short, 'man' does not include 'woman,' nor are the terms interchangeable. Asking a woman to behave as a reasonable man places her violent behaviour - when it does not comport with a male norm - outside the boundaries of reason." Taylor, supra note 75 , at $1679,1691-92$.

77. Rosen, supra note 74 , at 34 .

78. It is well known that historically women have been treated as inferior to men. For example, in Roman times, a husband was allowed to employ reasonable amount of violence to discipline or chastise his wife. English rape laws regarded rape as a crime committed against the victim's husband, father or fiancé. Marital rape was inconceivable. See Michael Dowd, Dispelling the Myths about the "Battered Woman's Defense": Towards a New Understanding, 19 FORDHAM URB. L.J. 567,568 (1992); Shane Wallace, Beyond Imminence: Evolving International Law and Battered Women's Right to Self-Defense, 71 U. CHI. L. REV. 1749, 1754 (2004). The common law doctrine of coverture also rendered women dependent on their husbands in private law matters. As Blackstone explained, "by marriage, the husband and wife are one person in law: that is, the very being or legal existence of the woman is suspended during the marriage, or at least is incorporated and consolidated into that of the husband." 1 WILLIAM BLACKSTONE, COMMENTARIES ON THE LAWS OF ENGLAND 442 (5th ed., Cavendish Publishing Limited, The Glass House, 2001) (1773). There also existed grave inequality in the law of homicide: "Petit treason ... may happen three ways: by a servant killing his master, a wife her husband, or an ecclesiastical person ... his superior, to whom he owes faith and obedience. ... So if a wife ... kills [her] ... husband, she is a traitor. The punishment of petit treason . . . in a woman [is] to be drawn and burned. ..." Id. at 203-04.

79. The concept of proportionality has also been criticised, for women are often physically weaker than men, which sometimes compels them to employ more force in comparison to men in similar conditions. The possibility of escape or retreat from the cyclical abuse also appears to be problematic for battered women due to socio-economic reasons or the possibility of further violence. See Gena Rachel Hatcher, The Gendered Nature of the Battered Woman Syndrome: Why Gender Neutrality Does Not Mean Equality, 59 N.Y.U. ANN. SURV. AM. L. 21, 22 (2004). 
defence claims. ${ }^{80}$ However, when the killing occurs in a non-confrontational scenario, courts often refuse to admit evidence of past abuse to support the claims of self-defence. ${ }^{81}$ In other words, there is a disinclination to admit expert testimony when the deadly force does not match the traditional temporal requirement, i.e., when the killing occurs during a lull in the violent encounter or some time after the illegal act or threat. Many courts focus on the temporal element and thus do not admit evidence relevant to self-defence claims unless the battered woman strikes the fatal blow against an actual or imminent aggressor. Therefore, the imminence rule usually deprives the battered woman of a valid claim of self-defence even if all the other requirements of selfdefence are met. ${ }^{82}$

Some feminist scholars, on the other hand, have underlined the significance of looking at a broader spectrum of time and context in which the fatal force was resorted to. ${ }^{83}$ This new insight recently led many jurisdictions to show greater latitude in the admission of expert testimony on battering and its effects to support female defendants' self-defence claims. The testimony is used to inform the fact-finder about the overall social context that led the battered woman to employ force against the quiescent abuser. Yet the main purpose is to shed light on why the "defendant reasonably believed that she was in imminent danger of death or great bodily harm." 84 This naturally brings the history of abuse within the calculus of the reasonable man standard and the imminence rule. The rationale is that an ordinary juror might not grasp the true nature of a particular incident without taking the underlying abusive history into account. ${ }^{85}$ A broader temporal understanding, ${ }^{86}$ however, enables the jury to

80. See Holly Maguigan, Battered Women and Self-Defense: Myths and Misconceptions in Current Reform Proposals, 140 U. PA. L. REV. 379, at 397-99 (1991); Nourse, supra note 41, at 1253; Fiona LeVerick, Killing In SElf-DEFENCE 91 (Andrew Ashworth ed., 2006).

81. See Skopets, supra note 34 , at 763 .

82. An example of a broader perspective of imminence can be observed in the case of State v. Leidholm: "Under the subjective standard the issue is not whether the circumstances attending the accused's use of force would be sufficient to create in the mind of a reasonable and prudent person the belief that the use of force is necessary to protect himself against immediate unlawful harm, but rather whether the circumstances are sufficient to induce in the accused an honest and reasonable belief that he must use force to defend himself against imminent harm ... . [Therefore] the finder of fact must view the circumstances attending an accused's use of force from the standpoint of the accused. .. . " State v. Leidholm, 334 N.W.2d 811, 817-18 (N.D. 1983); Martin E. Veinsreideris, Comment, The Prospective Effects of Modifying Existing Law to Accommodate Pre-emptive Self-Defense by Battered Women, 149 U. PA. L. REV. 613, 617-19 (2000).

83. See Jane Campbell Moriarty, While Dangers Gather: The Bush Pre-emption Doctrine, Battered Women, Imminence, and Anticipatory Self-Defense, 30 N.Y.U. REV. L. \& Soc. ChANGE 1, 2-3 (2005).

84. Janet Parrish, Trend Analysis: Expert Testimony on Battering and its Effects in Criminal Cases, 11 WIS. WOMEN's L. J. 75, 79 (1996).

85. See Hatcher, supra note 79, at 22.

86. Without doubt, the determination of one's intent and culpability is closely linked to the choice of time-frame. In this respect, the choice of adopting a narrower or broader time frame might (depending on the concrete circumstances of each case) change the judgement 
understand the abused woman's particular experiences with her abuser and the former's "heightened ability to sense that she was in grave danger at the time of killing. It provides the jury with the appropriate context in which to decide whether her apprehension of imminent danger of death or great bodily harm was reasonable."

It has also been posited that women do not commit homicide as often as men do. When they do, however, they usually kill their partners in response to constant abuse. In this respect, some feminist commentators, among others, legitimately questioned the validity of the reasonable man standard which sometimes undermines the claims of battered women in self-defence cases, ${ }^{88}$ because it is premised on the way in which men stereotypically respond to imminent aggression. This ignores the fact that "women do not and cannot respond immediately and proportionately to male violence, because of their inferior size, strength and fighting abilities." ${ }^{, 9}$

The state of "cumulative terror," economic dependence, threats of the abusing partner, and the ineffectiveness of the legal system are argued to be the main underlying causes of battered women's deadly strike. ${ }^{90}$ From this perspective, it has been maintained that the strict application of the temporal requirement should be removed from the traditional self-defence paradigm, because: "[b]attered women are most likely to be killed by their abusers after they leave the relationship or report abuse. Women should not be forced to await such a fate if they have a reasonable fear that it is inevitable, but not

about voluntariness in committing the wrongdoing. As Kelman notes, "often, conduct is deemed involuntary (or determined) rather than freely willed (or intentional) because we do not consider the defendant's earlier decisions that may have put him in the position of apparent choicelessness. Conversely, conduct that could be viewed as freely willed or voluntary if we looked only at the precise moment of the criminal incident is sometimes deemed involuntary because we open up the time frame to look at prior events that seem to compel or determine the defendant's conduct at the time of the incident." Mark Kelman, Interpretive Construction in the Substantive Criminal Law, 33 STAN. L. REV. 591, 594 (1981).

87. M. Elizabeth Schneider, Resistance to Equality, 57 U. PITT. L. REV. 477, 511 (1996).

88. Such criticism has also been directed at provocation cases which reflect a male understanding of losing self-control, i.e., in a "sudden and temporary" manner. It is argued that women generally experience a "slow burn" anger. See Aileen McColgan, General Defences, in Feminist Perspectives on Criminal Law 145 (Donald Nicolson \& Lois Bibbings eds., Cavendish Publishing 2000). Interestingly, in Camplin, Lord Diplock stated: "[F]or the purposes of the law of provocation the 'reasonable person' has never been confined to the adult male. It means an ordinary person of either sex, not exceptionally excitable or pugnacious, but possessed of such powers of self-control as everyone is entitled to expect that his fellow citizens will exercise in society as it is today." DPP v. Camplin [1978] AC 705, 716-17 (H.L.).

89. Donald Nicolson, Criminal Law and Feminism, in Feminist PerspeCtives ON CRIMINAL LAW, supra note 88, at 12.

90. M. J. Willoughby, Comment, Rendering Each Woman Her Due: Can a Battered Woman Claim Self-Defense When She Kills Her Sleeping Batterer, 38 U. KAN. L. REV. 169, 170-71 (1989). Although most jurisdictions do not impose a formal duty of retreat, Battered Woman Syndrome is employed to explain why the woman did not leave her abusive partner despite the consistent pattern of violence within the relationship. See David L. Faigman \& Amy J. Wright, Battered Woman Syndrome in the Age of Science, 39 ARIz. L. REV. 67, 81 (1997). 
necessarily imminent." M11 More importantly, the "concept of imminence has no significance independent of the notion of necessity." 92 In other words, since the main pillar of self-defence is the "necessity" to resort to force, the requirement of imminence should only be regarded as a "translator," or "proxy" for necessity.

Rosen, in this context, argues that imminence is required merely "because of the fear that without imminence there is no assurance that the defensive action is necessary to avoid the harm." 93 Similarly, Murdoch notes that "imminence is merely a way of measuring necessity"; thus, if these two concepts conflict, "imminence should not be permitted to interfere." this school of thought asserts that a proper application of the necessity requirement is sufficient to prevent possible abuses of self-defence in cases where the threat is not imminent.

This point is bolstered by Paul Robinson's well-known leaking ship hypothetical, in which the crew of a vessel discovers a slow leak shortly after leaving the port for a long journey. The Captain of the ship unreasonably refuses the request of the crew to cancel the journey. Absent intervention, the slow leak will capsize the vessel within two days. Therefore, although the leak does not pose an imminent danger, it definitely poses a certain future risk to the lives of the crew. The question is whether the sailors should mutiny to gain control of the vessel while they are close to the shore and have the chance to survive, or wait until the danger is imminent, even though waiting means they will be too far away from the port where their chance of survival would be slim. ${ }^{95}$ Once the dilemma is assessed within the narrow calculus of mutiny and the certainty of facing death, the solution appears to lie in discarding the requirement of imminence. However, the imminence and necessity rules, although closely connected, have distinct roles. An incipient threat, in the face of inaction, may ripen into an imminent danger, but this does not automatically entitle the individual to invoke deadly force; because, as argued earlier, if the threat is merely incipient, it is the right and obligation of the state apparatus, in the first place, to extend its protection to the would-be victim. If the state is capable of thwarting a non-imminent threat then the individual must not take the law into his own hands, for defensive lethal action is meant to be a measure of last resort.

91. Alafair S. Burke, Rational Actors, Self-Defense, and Duress: Making Sense, Not Syndromes, out of the Battered Woman, 81 N.C. L. REV. 211, 274 (2002).

92. See Richard A. Rosen, On Self-defense, Imminence, and Women Who Kill Their Batterers, 71 N.C. L. REV. 371,380-81 (1993).

93. Id.

94. Jeffrey B. Murdoch, Is Imminence Really Necessity: Reconciling Traditional SelfDefense Doctrine with the Battered Woman Syndrome, 20 N. ILL. U. L. REV. 191, 212 (2000). 952 PaUl RoBInSON, CRIMINAL LAW DEFENCES 56-57 (1984); Rockefeller, supra note 60, at 139. 


\section{THE POLITICAL CHARACTER OF THE IMMINENCE RULE}

Criminal law aims to protect human life at all costs; thus, private force may only be inflicted after the exhaustion of all possible non-violent alternatives. Self-defence, therefore, naturally has a social dimension. As Kremnitzer points out, through the act of self-defence, the individual is not only protecting his personal autonomy, but his action also has an impact upon the legal and social order: ${ }^{96}$

By virtue of his action, the law-breaker has become an enemy of the law in the broad sense of the word. When his victim employs self-defence to resist him, he is serving as the representative and defender of society, the public order and the legal system (since his action is meant to neutralize the violation of law created by the illegal act). Self-defence in such a situation is not only justified, it is in effect, an "an acte de police," since the authority charged with enforcing the law would not - had it been present at the time - have acted differently from the person employing it, and his act thus serves the public's interest in the deterrence and prevention of crime. $^{97}$

Of course, the social dimension of self-defence only becomes visible against unlawful aggression posed by culpable aggressors. ${ }^{98}$ It is such aggression against the would-be victim's individual autonomy and community rules that makes the right to self-defence understandable. ${ }^{99}$ However, individuals are not allowed to undertake an acte de police, as posited by Kremnitzer, because selfdefence is neither a punishment nor an act of law enforcement. It is rather an act of emergency that is temporally and materially confined with the narrow purpose of warding off the pending threat, not to re-establish the disturbed public order or to penalize the offender. Besides, state authorities -had the police been present at the very time of the illegal attack - could well employ less or even no force to neutralize the aggressor due to the deterrent effect they create upon the would-be offender or their experience and ability in containing violence. The defender is, therefore, not allowed to assume the role of the state machine to prevent violence from plaguing society or to re-establish social order. As Fletcher argues, the requirement of imminence has a political

96. Mordechai Kremnitzer, Proportionality and the Psychotic Aggressor: Another View, 18 ISR. L. REV. 178, 189 (1983).

97. Id. at 190.

98. Id. at 195; Mordechai Kremnitzer \& Khalid Ghanayim, Proportionality and the Aggressor's Culpability in Self-Defence, 39 TULSA L. REV. 875, 885-86 (2004).

99. K. K. Ferzan, Defending Imminence: From Battered Women to Iraq, 46 ARZ. L. REV. 213,259 (2004). 
character, rather than moral: ${ }^{100}$

The issue is the proper allocation of authority between the state and the citizen. When the requirement is not met, when individuals engage in pre-emptive attacks against suspected future aggressors, we fault them on political grounds. They exceed their authority as citizens; they take the "law into their own hands." Precisely because the issue is political rather than moral, the requirement must be both objective and public. There must be a signal to the community that this is an incident in which the law ceases to protect, that the individual must secure his or her own safety. ${ }^{101}$

This stance is consistent with the theoretical role of the state: by placing itself above the conflicting parties, it ensures security and peace in society. Indeed, the concept of security has long been viewed as the centrepiece of theorizing about the state apparatus. ${ }^{102}$ This finds its early formulations in Aquinas' philosophy where the power to use national force was exclusively deemed to be the function of the legitimate authority. To Aquinas, a private individual had no business in declaring warfare, nor was he allowed to resort to violence if he was in a position to seek redress of grievances by appealing to the judgment of his superiors. ${ }^{103}$

Security is also a critical concept in Locke's state theory. Locke regarded the state of nature as a "state of perfect equality" where "there ... [was] no superiority or jurisdiction of one over another." 104 However, violence gave rise to the state and the institution of punishment. ${ }^{105}$ By disturbing the peace and safety of the community, the wrongdoer posed danger to mankind against

100. George P. Fletcher, Domination in the Theory of Justification and Excuse, 57 U. PITT. L. REV. 553, 570 (1996).

101. Id.

102. V.F. Nourse, Reconceptualizing Criminal Law Defenses 151 U. PA. L. REV. 1691, 1736 (2003). Marxist theory, in this respect, explains the emergence of the state with the irreconcilable contradictions between classes with conflicting economic interests. In order to prevent these classes from annihilating each other, reasons Engels, "a power becomes necessary that stands apparently above the society and has the function of keeping down the conflicts and maintaining order." Frederick Engels, The Origin of The Family, Private Property, and THE STATE 206 (Ernest Untermann trans., Charles H. Kerr 1902).

103. Aquinas, supra note 22, at 81; Thomas Aquinas, St. Thomas Aquinas: PhIlosophical Texts 348 (Thomas Gilby trans., Oxford University Press 1967) (1951). By allowing individuals to use force in the absence of state protection, Augustine radically departed from Aquinas' philosophy where private use of force was deemed unlawful on the ground that such an act would involve hatred and lack of love. According to Augustine, only officials could kill without being motivated by sinful sentiments. See FREDERICK HOOKER RUSSELL, THE JUST WAR IN THE MIDDLE AGES 18 (Walter Ullman ed., Cambridge University Press, 1977) (1975).

104. John LoCke, The SeCOND TREATISE OF GovernMeNT 4-6 (C.B. Macpherson ed., Hackett Publishing Co. Inc., 1980) (1690).

105. Id. at 7 . 
whom institutional measures had to be applied. ${ }^{106}$ According to Locke, only lawful authorities could be the legitimate agent of force except in cases where there was no chance to appeal to the common superior for relief:

[B]ecause the law, which was made for my preservation, where it cannot interpose to secure my life from present force, which, if lost, is capable of no reparation, permits me my own defence and the right of war, a liberty to kill the aggressor, because the aggressor allows not time to appeal to our common judge, nor the decision of the law, for remedy in a case where the mischief may be irreparable. ${ }^{107}$

Again, Hobbes assumed that the "social contract" was concluded by man for self-preservation. In the state of nature, he argued, "every man will, and may lawfully rely on his own strength and art, for caution against all other men." 108 Furthermore, nature had made men so equal in the faculties of body and mind that even "the weakest has strength enough to kill the strongest, either by secret machination, or by confederacy with others, that are in the same danger with himself." 109 Therefore, the key solution to the problem of violence lied in the urgent task of establishing a sovereign power, namely the Leviathan, in front of whom men had to stand in awe and be tied together in security by the fear of punishment. ${ }^{110}$ The legitimacy of this sovereign power would last as long as it provided security to its subjects. Consequently, to Hobbes, the use of private force could be used only when Leviathan failed to provide protection. ${ }^{111}$

Montesquieu in his seminal work, The Spirit of the Laws, came to a similar conclusion:

With individuals the right of natural defence does not imply a necessity of attacking. Instead of attacking they need only have recourse to proper tribunals. They cannot therefore exercise this right of defence but in sudden cases, when immediate death would be the consequence of waiting for the assistance of the law. ${ }^{12}$

106. Id.

107. Id. at 13.

108. Thomas Hobbes, Leviathan: Or, tHE MATter, Forme \& POWER of a COMMONWEALTH, ECClESIASTICAL AND CIVIL 115 (A.R. Waller ed., Cambridge University Press 1904); Kinji Akashi, Hobbes's Relevance to the Modern Law of Nations, 2 J. HIST. INT'LL. 199 (2000).

109. HOBBES, supra note 108 , at 115.

110. Id.

111. To Hobbes, right of self-defence was a natural right which could not be relinquished by any Covenant: "In the making of a Common-wealth, every man giveth away the right of defending another; but not of defending himself." Id. at 156, 224.

112. Baron De Montesquieu \& JeAn Jacques Rousseau, The SPIRIT ofLaws 62 (Robert 
Blackstone's authoritative Commentaries on the Laws of England confirms this position:

This right of natural defence does not imply a right of attacking: for, instead of attacking one another for injuries past or impending, men need only have recourse to the proper tribunals of justice. They cannot therefore legally exercise this right of preventive defence, but in sudden and violent cases; when certain and immediate suffering would be the consequence of waiting for the assistance of the law. Wherefore, to excuse homicide by the plea of self-defence, it must appear that the slayer had no other possible means of escaping from his assailant. ${ }^{113}$

The imminence rule, therefore, not only confirms the force monopoly held by the state, but it also aims to prevent putative defenders from taking innocent lives on the basis of their subjective and speculative reasoning. The importance of letting no man be his own judge and the need for an objective body to settle the disputes between individuals was noticed by influential jurists and philosophers. Locke, for instance, noted that:

[1]t is unreasonable for men to be judges in their own cases, that self-love will make men partial to themselves and their friends, and, on the other side, that ill-nature, passion, and revenge will carry them too far in punishing others, and hence nothing but confusion and disorder will follow; and that therefore God has certainly appointed government to restrain the partiality and violence of men. ${ }^{114}$

Grotius also recognized the importance of an objective body in resolving disputes between conflicting parties:

It is ... much more consistent with moral standards, and more conducive to the peace of individuals, that a matter be judicially investigated by one who has no personal interest in it, than that individuals, too often having only their own interests in view, should seek by their own hands to obtain that which they consider right .... ${ }^{115}$

The imminence rule, in this context, prevents the superfluous use of lethal force by requiring individuals to retreat or exhaust all viable non-violent

113. 2 William Blackstone, Commentaries on the Laws of ENGland 145 (5th ed., Cavendish Publishing Limited, The Glass House, 2001).

114. LOCKE, supra note 104, at 9.

115. GROTIUS, supra note 20 , at bk. I/III//II 
responses to counter an incipient threat before it matures into an imminent risk. This prevents the abuse of the self-defence doctrine and reaffirms the role of the state whose monopoly on the use of force only cedes when it cannot provide protection to putative victims.

Returning to Robinson's scenario, it should be reiterated that the dilemma is presented within the narrow frame of mutiny or death, excluding other possible alternatives. Firstly, since the crew determines the slow but inevitable leak, they may simply inform the police about the definite risk they face. This would bring the legitimate state intervention into play. Naturally, as the state is not bound by the imminence rule it may use preventive force, if necessary, to protect the lives of the sailors. ${ }^{116}$ Secondly, it appears that the captain acts imprudently for refusing the crew's demands to cancel the perilous journey during which the incipient threat would certainly ripen into an inevitable danger. The crew, therefore, faces an already immediate threat to their lives and liberties, which, if state protection is not available, entitles the crew to use a proportionate amount of force to take control of the vessel. The existence of the temporal requirement, therefore, does not necessarily mean that individuals must await death like "sitting ducks"; on the contrary, one of its main functions is to press individuals to take prudent steps before prematurely resorting to deadly force.

\section{THE INTERCONNECTION BETWEEN THE ELEMENTS OF SELF-DEFENCE: JUSTIFIED FORCE VERSUS ACTS OF RETALIATION}

The temporal requirement is closely connected with the notions of necessity and proportionality; that is, imminence provides an objective yardstick against which the necessity of private force can be measured and the interests of the putative aggressor and defender can be balanced. Indeed, absent an imminent threat, it is not only difficult to judge to a degree of certainty that the anticipated harm would have ever occurred (necessity), but also whether the defendant could have avoided the lethal threat without employing any force, or just enough force to repel the threat (proportionality) until the state steps to the forefront to contain the situation. Since defensive action is meant to protect a vital interest of the defendant, such as his life, liberty, or physical integrity, the imminence rule enables the adjudicator to assess whether such an interest was actually threatened and whether a just balance between the harm inflicted and the good preserved was properly struck by the defendant.

In other words, the imminence rule, by requiring the would-be victim to seek non-violent alternatives to deal with the perceived threat, ensures that lethal force is only invoked against threats that are present or likely to materialize, and that the defensive force is employed within a concrete scenario 
where the notion of proportionality can appropriately be appraised. This point is of particular relevance for battered women cases, where the majority of abuse victims face a certain level of violence that does not meet the threshold of death or bodily harm to justify the use of lethal force. Indeed, except for extreme cases (such as the well-known Norman ${ }^{117}$ case), "the fact that a battered woman has been assaulted on many occasions in the past but has not been killed might suggest that she is unlikely to be killed by her partner in the future."118 From this perspective, the temporal requirement is inseparably interconnected with the elements of necessity and proportionality, and its relaxation would adversely affect the whole matrix of the self-defence doctrine.

Of equal significance, the temporal requirement ensures that the deadly action, carried out under the flag of self-defence, has been a preventive measure, rather than an act of retaliation. In criminal law, actors frequently establish their own justice through vengeance, and in order to escape punishment they usually hide behind the shield of self-defence. ${ }^{119}$ In a successful self-defence case, however, the focus must shift from past to future violence; that is, from retaliation, if that was the real motive, to an argument of defending oneself from an imminent threat. This, Fletcher notes, "is the standard manoeuvre in battered-wife cases. In view of her prior abuse, the wife arguably has reason to fear renewed violence. Killing the husband while he is asleep then comes into focus as an arguably legitimate defensive response rather than an illegitimate act of vengeance for past wrongs." 120

Of course, battered women are legitimately concerned about the repeated cycle of violence (which renders them helpless, immobilized, passive, and thus unable to break the vicious circle in a non-violent fashion), the masculine construction of criminal law and the failure of state agencies to protect them. ${ }^{121}$ Given the dreadful conditions they are in, it might appear plausible to grant them leniency in non-confrontational killings. In this vein, Ayyildiz makes an interesting argument:

The battered woman is by definition a victim, one who has not received justice, one who has not seen her batterer punished for the abuse he has heaped upon her. Thus, by killing her batterer, the battered woman becomes a spontaneous vigilante -she apprehends a criminal that the law has failed to bring to justice and metes out the punishment he richly deserves .... Thus, rather than continue waiting for the state, all the while

117. State v. Norman, 378 S.E. 2 d 8 (N.C. 1989).

118. LEVERICK, supra note 80 , at $91-92$.

119. See James Q. Whitman, Between Self-Defense and Vengeance/between Social Contract and Monopoly of Violence, 39 TULSA L. REV. 901,902 (2004).

120. GEORGE P. FleTCHER, A CRIME of Sel F-DEFENCE: BeRnHARd GoETz AND THE LAW ON TRIAL 22 (1988).

121. See Celia Wells, Battered Woman Syndrome and Defences to Homicide: Where Now?, 14 Legal STUd. 266 (1994). 
receiving beating after beating, the battered woman, by killing her abuser, repairs the moral order herself. ${ }^{122}$

This view, however, fails to notice the political rationale of the selfdefence doctrine. It is important to emphasize that the battered woman's selfdefence claim cannot be based upon the notion of just desert. Indeed, even if the death of the abuser might satisfy the common sense of moral justice, if the lethal strike does not fall within the confines of the self-defence doctrine, it cannot be regarded as an act of justification. ${ }^{123}$ As noted above, self-defence is neither a punitive measure nor an act of law enforcement; it is rather a measure of last resort to fend off an illegal attack in the absence of state protection. Moreover, a valid self-defence claim requires the intent of the defendant to be defensive as well, ${ }^{124}$ that is, a fatal act must not have been motivated by the aggressor's past misdemeanour. ${ }^{125}$ If the theory of self-defence was built upon the notions of punishment and just desert, this would merely open the doors for vigilantism against suspected offenders. ${ }^{126}$ In centralized legal orders, criminal punishment is a prerogative of legitimate state power. In Fletcher's language, "criminal punishment is the most elementary and obvious expression of the state's sovereign power." 127 The battered woman, as a result, may only justify her killing by showing that she was in imminent danger of being killed or seriously injured, and that the employment of deadly force was the only alternative to ward off the threat involved. ${ }^{128}$ Therefore, no matter how much one is inclined to consider the killing of the abusing partner as "just," the criminal procedure must go beyond the luring trap of "desert," and establish whether or not the elements of the offence/defence are satisfied.

122. Elisabeth Ayyildiz, When Battered Woman's Syndrome Does Not Go Far Enough: The Battered Woman as Vigilante, 4 AM. U. J. GENDER \& L. 141, 147-48 (1996).

123. As Weinreb asserts, "[j] ustice as desert is contrasted with the idea of entitlement, with which it is said commonly to be confused. Entitlements are the product or rules, which may, but need not, reflect desert and, therefore, justice." Lloyd L. Weinreb, The Complete Idea of Justice, 51 U. CHI. L. REv. 752, 752 (1984).

124. This position finds its roots in Aquinas' understanding of individual self-defence, known as the double effect doctrine, which also had profoundly influenced the justification of defensive wars in international law. According to this doctrine, an act might lead to a good and bad result; yet in order for its moral permissibility the intended act must be good, the ensuing bad result must not be desired, and that the intended good must be proportionate to the bad outcome. See Thomas Aquinas, Polmical Writings 263-64 (R.W. Dyson ed., trans., Cambridge University Press 2002).

125. See 1 George P. Fletcher, The Grammar of Criminal law: american, COMPARATIVE, AND INTERNATIONAL 14 (2007).

126. See George P. Fletcher, Self-Defense as a Justification for Punishment, 12 CARDOZO L. REv. 859, 865 (1991).

127. George P. Fletcher, Fall and Rise of Criminal Theory, 1 BUFF. CRIM. L. REV. 275, 287 (1998).

128. John W. Roberts, Between the Heat of Passion and Cold Blood: Battered Woman's Syndrome as an Excuse for Self-Defence in Non-Confrontational Homicides, 27 LAW \& PSYCHOL. REV. 135, 136 (2003). 
This point is also decisive for the theory of justification and excuse: an outwardly wrongful act might be excused or justified by society, which consequently may exclude the actor from criminal liability. Although both defences are based on the absence of the requisite mens rea, a necessary condition for culpability, their theoretical bases are fundamentally different. A successful defence of justification renders an otherwise criminal conduct legal, because the exceptional circumstances under which an ostensibly wrongdoing was committed negate criminal liability. An excuse defence, on the other hand, recognizes the illegal character of the act, yet posits a lack of culpability due to the actor's incapacity for criminal condemnation. ${ }^{129}$ In this context, the Canadian Law Reform Commission notes that:

Despite their common fundamental nature, duress, selfdefence and necessity [should be] kept separate ... [because] the distinction is based on moral differences between the three defences.... In self-defence the accused seeks protection against aggression and in so doing promotes a value supported by the law. In duress, he avoids harm wrongfully threatened to him but does so at the expense of an innocent third party or by contravention of the law and therefore does not promote a value supported by the law. In necessity he may sometimes promote a value supported by the law and contravene the letter of the law to secure some greater good (e.g. an unlicensed motorist drives an emergency case to hospital to save life); at other times he may fail to promote such a value but may avoid harm to himself at the expense of an innocent person or of contravention of the law (e.g. a shipwrecked sailor saves himself by repelling another from a plank sufficient to carry one). ${ }^{130}$

The difference is not merely based on moral grounds though; instead, justification defences also involve serious legal consequences. Indeed, in justification defences, the actor does not breach any legal norm, but only resorts to his legal/moral right to protect his vital interests. Justification claims stress the rightfulness of an act, which nominally violates the law and is subject to punishment. ${ }^{131}$ In other words, a justified conduct no longer fits into the paradigm of a criminal offence. Claims of excuse, on the other hand, concede the wrongfulness of the act committed, but attempt to avoid the attribution of

129. See Peter D. W. Heberling, Justification: The Impact of the Model Penal Code on Statutory Reform, 75 COLUM. L. REV. 914, 916 (1975).

130. Canadian Law Reform Commission, Criminal Law the General Part: Liability and Defences 90-91 (Ottowa: Working Paper 29 1982) (emphasis added).

131. See George P. Fletcher, RethinkIng Criminal LaW 69 (Little, Brown and Company 1978). 
criminal liability to the actor due to extreme circumstances under which he acted, or his diminished capacity in discerning the right from the wrong. The often-quoted passage of Hart clearly illustrates this point:

In the case of 'justification' what is done is regarded as something that the law does not condemn or even welcomes. But when the killing ... is excused, the criminal responsibility is excluded on a different footing. What has been done is something which is deplored, but the psychological state of the agent when he did it exemplifies one or more of a variety of conditions which are held to rule out the public condemnation and punishment of individuals. This is a requirement of fairness or of justice to individuals. ${ }^{132}$

The difference between justification and excuse plays a significant role in determining the rights and obligations of the third parties as well; i.e., when the actor is merely excused, this does not affect others' right to resist or assist the wrongful actor, for excuses are personal to the actor. A justified act, however, not only deprives the wrongful actor of the right to resist, but it also enables, if not encourages, the third parties to assist the justified actor. ${ }^{133}$ More importantly, a justified act, in contrast to an excused act, may be modelled by other members of society. ${ }^{134}$ Hence, while the employment of fatal force has been one of the gravest threats posed against the social order, ${ }^{135}$ societies have found it an acceptable form of behaviour, if performed within the legal contours of self-defence. Defensive force, in other words, may serve as guidance for human behaviour that can be performed by other individuals under analogous circumstances.

The distortion of the self-defence doctrine may therefore legitimize the notion of private punishment by providing a "licence to kill" where the actor subjectively believes (or claims to have believed) that deadly force is necessary

132. HLA HART, PUNISHMENT AND RESPONSIBILITY: ESSAYS ON THE PHILOSOPHY OF LAW 1314 (Oxford University Press 1968).

133. See George P. Fletcher, The Right and the Reasonable, 98 HARV. L. REV. 949, 954 (1985).

134. One of the main functions of the law is to regulate individual behaviour by attaching sanctions to untoward acts. KELSEN, supra note 10, at 320 . In other words, law envisages a rule of human conduct that is deemed obligatory and binding upon all citizens to govern the relationships between individuals with the promise of a suitable sanction for the disobedient. See J. M. Coady, Morality and the Law, 1 U. BRIT. Colum. L. Rev. 442, 442 (1959).

135. Homicide has always been met by a solemn reaction by usually depriving the perpetrator of his life or liberty for long years. It is the function of social order to bring about a certain type of behaviour that is deemed socially desirable. Societies, to this end, command certain mode of human conduct by attaching punishment to the opposite behaviour. As Kelsen notes, "[f]rom a sociological-psychological point of view, reward or punishment are ordered to make the desire for reward and the fear of punishment the motives for a socially desirable behavio[u]r." KELSEN, supra note 10, at 26. 
to repel the threat, even if objectively the anticipated attack is not imminent. In addition, the phenomena of dominance, exploitation, abuse, violence and ensuing helplessness, or other detrimental mental conditions, are not peculiar to battered women. Such circumstances do affect the members of other vulnerable groups, including the members of ethnic, religious and linguistic minorities, homosexuals, ${ }^{136}$ children, and the disabled in their daily environments where all forms of authority can, in one way or another, be exercised. The elimination of the imminence rule would be of no help other than curing the symptoms without removing the root causes of the problem.

The concept of imminence cannot merely be relaxed with respect to battered women's self-defence claims, because the law must be applied equally to those under analogous circumstances, which might finally render the right of self-defence meaningless. The newly formulated syndromes, including the oldage syndrome, battered children syndrome, the battered husband syndrome, ${ }^{137}$ the holocaust syndrome, the battered person syndrome, the Vietnam War syndrome, and the premenstrual syndrome, which mushroomed after the introduction of the battered woman syndrome, indicate the danger in breaking down the traditional contours of the self-defence doctrine. ${ }^{138}$

136. Interestingly, particularly in the United States, the notion of "homosexual advance defence" can be raised in provocation cases to mitigate the sentence. Homosexual panic has been invoked to back up defendants' claim that the use of lethal force was triggered by an acute panic they suffered as a result of the belief that they were being molested sexually. Celia Wells, Provocation: The Case for Abolition, in RETHINKING ENGLISH HOMICIDE LAW 85, 90 (Andrew Ashworth \& Barry Mitchell eds., Oxford University Press 2000). The "homosexual panic" defence has legitimately been criticised for institutionalising "homophobia that perpetuates paranoia of gay men and lesbians and justifies extreme violence in the face of a 'homosexual confrontation."' Allyson M. Lunny, Provocation and 'Homosexual' Advance: Masculinised Subjects as Threat, Masculinised Subjects Under Threat, 12 Soc. LEGAL STUD. 311, 312 (2003). 137 Studies indicate that a significant number of men exist who have been the victims of spousal abuse. However, such abused husbands, due to their fear of ridicule and shame, often do not admit that they have been the victims of abuse by their wives. Such battered spouses at times claim self-defence as they kill their spouses in non-confrontational settings. For instance, in the case of Walker the defendant unsuccessfully claimed that he was an emotionally battered husband and that his mind could not think of any non-violent option to end the repressive situation he was in. See People v. Walker, 145 Cal App.3d 886, 900 (Cal. Ct. App. 1983). Some commentators argue that a battered man, similar to a battered woman, has different perceptions of imminent danger. Therefore, "even though men have not had the same cultural background advocating meekness, passivity, and submissiveness, this would not preclude them from developing the same personality traits common to battered women. The lack of societalbased reasons for passivity should not be the determinative factor for denying battered husbands the same treatment by the courts as battered wives." Nancy L. Guerin, People v. Walker: The Battered Husband Defence, 7 CRIM. JUST. J. 153, 168 (1984); see also Richard Jackson Harris \& Cynthia A. Cook, Attributions about Spouse Abuse: It Matters Who the Batterers and Victims Are, 30 SEX ROLES 553 (1994).

138. In the Werner case, one of the judges wittily observed that there already existed the Battered Woman Syndrome, the Battered Child Syndrome, the Battered Husband Syndrome, the Police Officer Syndrome, the Battle-Weary Syndrome, and the Holocaust Syndrome, and that further syndromes will certainly appear, such as the Appellate Court Judge Syndrome. See Werner v State, 711 S.W.2d 639, 649 (Tex. Crim. App. 1986); BoAZ SANGERo, SelF-DefenCE 
The same logic applies to international relations, where self-defence constitutes the sole justification for the use of force without Security Council authorization. ${ }^{139}$ Therefore, if the Iraq War is to be recognized as a legitimate form of anticipatory self-defence, then it must legally be categorized as a justified act, which may be used as a norm setting paradigm due to its legal character. Put differently, if the claims of the Bush Administration are accepted, then most states in the world's hot spots, including Pakistan and India, North and South Korea, Israel and Syria, Congo and Rwanda, and Iran and the United States, could legitimately be the objects of alleged "anticipatory" self-defence. ${ }^{140}$ In his Nobel Peace Prize Lecture, former U.S. President Jimmy Carter also underlined such danger: "Today there are at least eight nuclear powers on earth, and three of them are threatening to their neighbours in areas of great international tension. For powerful countries to adopt a principle of preventive war may well set an example that can have catastrophic consequences." 141

However, the main difference between the claims of battered women and those of the United States lies in the fact that the former suffer from systematic abuse and violence, giving rise to serious physical and mental conditions that might trigger the wrong belief that the victim was in grave danger at the time of killing. This is a typical example of an excuse defence. Indeed, as discussed earlier, when a faulty act is committed owing to the agent's mistaken belief, society often excuses the innocuous agent for causing a needless harm, rather than justifying him. Uniacke, in this respect, rightly notes that "to excuse an agent implies that his or her conduct was wrongful by some standard; and this standard can be derived from a more informed, a more objective perspective than that of the agent in the circumstances. ${ }^{142}$ In the light of the above, battered women's mistaken belief as to the circumstances may arguably be regarded as an excuse of the agent.

IN CRIMINAL LAW 345 (2006); Rosen, supra note 74, at 15; see generally Tina Beers, Children Who Kill Their Parents: The Battered Child Syndrome, 14 CHILD. LEGAL RTS. J. 2 (1993).

139. Similar to domestic law, the concept of necessity, or rather, emergency actions, did exist in international law. Such acts differed from reprisals, which required the existence of prior unlawful acts by target states. In other words, acts of necessity could be initiated without the need for culpability on the part of the target state. Such forceful measures were justified under the basic need of survival, where the actor intended to avoid the danger at the expense of the innocent third party. The archetypical example of an act of necessity was provided by Britain in 1807, where the partial destruction of the Danish fleet and the capture of the remainder at Copenhagen were justified with the intent to stop the advancing French armies that could have invaded Denmark and capture the Danish fleet in order to use it against the British. Another famous example is the invasion of the then neutral Belgium by Germany on the ground of imperious necessity. The rationale was quite similar, namely that Belgium was to be invaded by France through which French attacks could be realized against Germany. The invasion was also aimed at forestalling the anticipated threat by France. See NEFF, supra note 47, at 239-40.

140. See David J. Luban, Preventive War, 32 Phil. \& Pub AfF. 207, 227 (2004).

141. Jimmy Carter, Nobel Peace Prize Speech (Dec. 10, 2002), http://news.bbc.co.uk/1/hi/world/americas/2562301.stm.

142. Suzanne Uniacke, Permissible Kullng: The Self-Defence Justification of HoMICIDE 16 (Jules Coleman ed., 1994). 
The United States, on the other hand, never faced an actual attack, nor was in a position to reasonably believe that Iraq posed an imminent threat against it. Neither can the mental conditions of the battered woman be applied to the United States, for national self-defence is governed by objective standards. Indeed, the right to national self-defence requires credible proof that lethal force is directed at an actual ${ }^{143}$ or imminent danger where no other alternative exists. The International Court of Justice (ICJ) confirms this strict approach in the case of Oil Platforms: ${ }^{144}$

[I]n order to establish that it was legally justified in attacking the Iranian platforms in exercise of the right of individual selfdefence, the United States has to show that attacks had been made upon it for which Iran was responsible; and that those attacks were of such a nature as to be qualified as "armed attacks" within the meaning of that expression in Article 51 of the United Nations Charter, and as understood in customary law on the use of force. ... The United States must also show that its actions were necessary and proportional to the armed attack made on it, and that the platforms were a legitimate military target open to attack in the exercise of self-defence. ${ }^{145}$

The United States, in the case of Iraq, lacked such evidence from the outset. Rather, to give the United States the benefit of the doubt and assume that its attack was not motivated by economic and political considerations, it, in any scenario, acted preventively to deny Iraq the potential to pose dangers in an indefinite future. Hence, Operation Iraqi Freedom is not an act of justification, and the category of excuse does not exist within the matrix of national force. Indeed, in international law, unlawful use of national force cannot be excused on the grounds of infancy, insanity, intoxication or any other condition that manipulates the decision making process. These are peculiar to individuals; therefore, states, particularly absent imminent danger, do not have the luxury of committing mistakes due to the magnitude and destructive nature of any military venture. Notably, wars are generally engaged in following serious domestic and international deliberations, particularly when peaceful alternatives fail or it becomes clear that they are unlikely to produce successful results. As Walzer rightly states, even in cases of imminent threats ${ }^{146}$ "[t] here is often

143. Thomas Franck, Comments on Chapters 7 and 8, in UNTED STATES HEGEMONY AND THE FOUNDATIONS OF INTERNATIONAL LAW, supra note 30, at 268.

144. Oil Platforms (Iran v. U.S.), 2003 I.C.J.161.

145. Id. at $\mathbb{I} 51$.

146. It is important to note that Al-Qaeda, which was paradoxically heavily supported by the United States and its allies during the Afghani-Russian war, had long been conducting terrorist activities against the United States, well before the September 11 attacks. See Chitra Ragavan, Tracing Terror's Roots, U.S. NEWS \& WORLD REP., Feb. 16, 2003, available at http://www.usnews.com/usnews/news/articles/030224/24wtc.htm; Richard Miniter, An 
plenty of time for deliberation, agonizing hours, days, even weeks of deliberation, when one doubts that war can be avoided and wonders whether or not to strike first."147 This was the case with the Iraq War where, despite the unprecedented worldwide protests against the commencement of hostilities, the matter was even taken to the Security Council as it appeared that authorization would not be granted.

\section{DOUBLE STANDARDS IN THE APPLICATION OF INTERNATIONAL LAW:} THE ELEMENT OF POWER

International law is aimed at fashioning common legal rules for nations that differ from one another in cultures, histories, languages, religions and economic, political and legal systems. ${ }^{148}$ Universalisation of international law cannot be separated from the notion of equal application of the law; yet, international affairs have always been characterized by extreme inequalities and dominated by a few powerful states. Indeed, even when the concept of sovereign equality was first coined, it was merely applicable to the newly emerged independent states in Europe following the "decline of the authority of the Holy Roman Empire and the disintegration of Christendom." 149 This inequality became blatantly evident with the positivist distinction between civilized and uncivilized nations where only the practices of European states were considered to be decisive in the formation of international law. ${ }^{150}$ NonEuropean states, in other words, were excluded from the domain of law and denied the capacity to assert their rights through legal means. ${ }^{151}$ It is, therefore, not wrong to say that the foundations of international law had largely been shaped by successive hegemons. ${ }^{152}$ Today, the U.N. Charter, despite its

Unheeded Warning, WALL ST. J., Sept. 30, 2003, available at http://www.opinionjournal.com/extra/?id=110004081; NOAM CHOMSKY, FAllED STATES: THE ABUSE OF POWER AND THE ASSAULT ON DEMOCRACY 22 (2006). For a list of Al-Qaeda's tertorist activities see Timeline: Al-Qaeda, BBC NEWs, http://news.bbc.co.uk/2/hi/3618762.stm.

147. See WALZER, supra note 26 , at 75.

148. Mark Weston Janis, The American Tradition of International Law: Exceptionalism and Universalism, 21 CONN. J. INT'L L. 211, 211-12 (2006).

149. Krisch, supra note 30 , at 138.

150. It is no accident that today Afghanistan, Iran, Iraq, North Korea and Libya are designated as "rogue states," a term used as a substitute for "uncivilized nations." This pejorative label evokes images of an aggressive state that regularly violates the norms of international law and which therefore cannot be deterred by peaceful means.

151. ANGHIE, supra note 68, at 54; Christine Gray, Intermational Law 1908-1983, 3 LEGAL STUD.267, 267-68 (1983).

152. Michael Byers, The Complexities of Foundational Change, in UNITED STATES HEGEMONY AND THE FOUNDATIONS OF INTERNATIONAL LAW, supra note 30, at 1. Interestingly, this contention, to a certain extent, overlaps with a feminist critique, which posits that the formation of legal discourse has never been neutral but "produced under conditions of patriarchy." CAROL SMART, FEMINISM AND THE POWER OF LAW 86 (Maureen Cain ed., 1989). This line of argument is somewhat reminiscent of the Marxist assertion that "[ $t]$ he ideas of the ruling class are in every epoch the ruling ideas, i.e. the class which is the ruling material force of society, is at the same time its ruling intellectual force." KARL MARX \& FREDERICK ENGELS, The GeRMAN IdEOLOGY 64 (C.J. Arthur Ed., Lawrence \& Wishart 1970) (1845). There is no 
reference to the principle of "sovereign equality,"153 contains a significant legal limit to the equality of member states, namely the binding character of the Security Council resolutions and the decisive role played by the permanent members in their adoption. ${ }^{154}$

Currently, the notion of equal application of the law is being challenged by the United States, ${ }^{155}$ which often acts according to its perceived interests, and whose superpower status evidently generates greater impact on the rules of the international community. ${ }^{156}$ The power of the United States is manifestly apparent when it undermines the process of international lawmaking in crucial areas from global warming and arms control to the International Criminal Court (ICC). ${ }^{157}$ It is, apparently, this very power that also exempts the United States from being labelled as a "rogue" when it refuses to cooperate with the international community on such critical matters.

An important illustration of American reluctance in undertaking international responsibilities and engaging with multilateral efforts was its decision to ignore the global effort of combating climate change, and its rejection of the Kyoto Protocol on the ground that it was "flawed" and not in the economic interest of the United States. ${ }^{158}$ The United States also prevented the adoption of a protocol to the Biological Weapons Convention, which would have introduced an effective inspection regime similar to that of the Nuclear Non-proliferation Treaty ${ }^{159}$ and the Chemical Weapons Convention. The U.S. Senate further blocked the Comprehensive Nuclear Test-Ban Treaty, and it appears that the Landmines Convention will also not be ratified by the United

denial that there exists a rather close connection between power/authority relations and the law, and that it is of extreme difficulty to detach the legal superstructure from the historical, sociological and economic circumstances of a given community. Patriarchy, in this sense, has undoubtedly contributed to the formation of the legal discourse, rather than being the sole determining factor.

153. U.N. Charter art. 2, para. 1.

154. Andreas Paulus, War against Iraq and the Future of International Law: Hegemony or Pluralism, 25 MICH. J. INTL'L L. 691, 724 (2004).

155. It is important to note that the United States, along with three other members of the Security Council, opposed an important General Assembly resolution in 1979, which condemned hegemonism in all its manifestations. Inadmissibility of the Policy of Hegemonism in International Relations, G.A. Res. 34/103, U.N. Doc. A/Res/34/103 (Dec. 14, 1979); Detlev F. Vagts, Hegemonic International Law, 95 AM. J. INT'L L. 843, 845 (2001). The resolution was apparently rejected since it equated Zionism with racism. See Thomas M. Franck, What Happens Now? The United Nations after Iraq, 97 AM. J. INT'L L. 607, 610 (2003).

156. Edward Kwakwa, The International Community, International Law, and the United States: Three in One, Two Against One, or One and the Same?, in UNITED STATES HEGEMONY AND THE FOUNDATIONS OF INTERNATIONAL LAW, supra note 30, at 37.

157. See id. at 4.

158. See Greg Kahn, Fate of the Kyoto Protocol under the Bush Administration, 21 BERKELEY J. INT'L L. 548, 548-49 (2003).

159. It is to be noted that the Non-Proliferation Treaty, currently the most significant tool to prevent the spread of nuclear weapons, is criticized for establishing a system of "nuclear apartheid," for it allows the nuclear powers to retain their weapons, yet prohibits the nonnuclear states from producing or acquiring nuclear armoury. See Antony Anghie, The War on Terror and Iraq in Historical Perspective, 43 OsGOODE HALL L. J. 45, 53 (2005). 
States in the foreseeable future. As Paulus argues, "the lack of an effective non-proliferation regime is not only due to the existence of 'rogue states,' but just as much to the U.S. reluctance to build on the existing institutions to control the further spread of WMD."160

The United States' renunciation of the Rome Treaty that established the ICC is another noteworthy example of American unilateralism. ${ }^{161}$ The United States rejected the jurisdiction of the ICC, simply because a special immunity from prosecution for United States nationals was not included in the Rome Statute. According to Defence Secretary Donald Rumsfeld, "there is a risk that the ICC could attempt to assert jurisdiction over U.S. service members, as well as civilians, involved in counterterrorist and other military operations something we cannot allow." 162

From this point of view, the United States arguably attempts to create explicit double standards in the application of international law. This apparently derives from its capacity to employ devastating force against any state that is perceived as hostile, willing to acquire WMD, or considered to be supporting terrorism. Yet, as long as the United States and its allies obstruct multilateral efforts and avoid undertaking international responsibilities, their complaints about the ineffectiveness of the collective security framework in forestalling modern threats posed by the "rogues" and "terrorists" will sound insincere. $^{163}$

While the United States' "ineffectiveness argument" is somewhat analogous to that of the battered woman's complaint about the negligent behaviour of the law enforcement authorities, which fail to take effective measures to prevent the vicious circle of domestic abuse, the weight of these two arguments fundamentally differ from one another. Indeed, the latter claim is put forward by a physically weak (relative to the abuser) and systematically abused person, who not only suffers severe psychological conditions, but who is also rarely taken seriously by law enforcement bodies. ${ }^{164}$ In contrast, the

160. Paulus, supra note 154 , at 723.

161. See Michael Walzer, ARguing About War 156-57 (2004).

162. Jim Garamone, U.S. Withdraws from International Criminal Court Treaty, U.S. Department of Defence, May 7, 2002 available at http://www.pentagon.mil/news/newsarticle.aspx ?id=44089. It is to be briefly noted that United States resistance has manifested itself in three extreme forms. Firstly, Congress passed a law, known as the "Hague Invasion Act," authorizing the President to employ any possible means, including the use of military force, to rescue United States citizens from the custody of the International Criminal Court. Secondly, the United States has engaged in a global effort to sign bilateral treaties, named as "Article 98 Agreements," with International Criminal Court member states, where parties agree not to turn one another's nationals over to the International Criminal Court. Thirdly, the United States lobbied states to abrogate the Rome Treaty, and cut off its military aid to states refusing to cooperate and sign the Article 98 agreements. See Luban, supra note 140 , at 238 .

163. See Paulus, supra note 154 , at $722-23$.

164. The case of Stonehouse is a striking example of how difficult it is for the battered woman to escape from her abuser or to prevent the escalating level of violence, particularly when confronted by the indifference of the relevant State authorities to end the cycle of abuse. 
United States, due to its superpower capabilities in all spheres, may not only implement its policies via force, but may also sit as a judge in its own cause. The decentralized and markedly politicized character of international law, ${ }^{165}$ in this respect, increases the United States' chance to engage in unilateral force, whenever convenient, and prevent any possible collective security measure against it.

It might of course be claimed that United States' unilateralism against incipient threats is a necessary response against unpredictable and premeditated terrorism that is sponsored by the "rogue states," which have no regard for the norms of international society and attempt to produce and proliferate WMD. It might further be claimed that the United States has been "traumatized" after the September 11 attacks, and thus more latitude must be accorded to its acts, just as the advocates of battered women sometimes argue. However, as Fletcher argues, "this aspect of domestic self-defence law is highly unlikely ever to be accepted in the international context," 166 because, as argued above, claims of excuse cannot be advanced by states in international law, they are peculiar to individuals.

The United States' attempt to broaden the scope of self-defence and

Commonwealth v. Stonehouse, 555 A.2d 772 (1989); see also Willoughby, supra note 900, at 170-171.

165. International law is considered to be a body of rules governing the mutual relations between states and other agents in international politics. Yet, the decentralized structure of the international legal system caused significant hesitation for many legal theorists to ascribe the character of "law" to international law on the ground that law cannot be separated from the notions of sanctions, force or coercion. To date, the questions of whether or not enforceability is an essential component of the law, whether the purpose of sanctions is that of law enforcement, punishment or retribution, and whether the concepts are applicable within the decentralized structure of the international legal system have not yet been conclusively settled. See Hedley BULl, THE ANARCHICAL SOCIETY: A STUdY OF ORdER IN WORLD POLITICS 124 (Columbia University Press, 3d. ed., 2002) (1977); Peter L. DeStefano, The Emerging Moral Framework of International Law, 1 FORDHAM INT'L L.J. 1, 1 (1977); Vera Gowlland-Debbas, Security Council Enforcement Action and Issues of State Responsibility, 43 INT'L \& COMP. L.Q. 55,59 (1994). Some consider enforceability to be a necessary characteristic for a valid legal system. For instance, in LEVIATHAN, Hobbes argues that "covenants, without the Sword, are but words, and of no strength to secure a man at all." HOBBES, supra note 108, at 115. Again in DE CiVE, he notes that law is sometimes confounded with counsel, yet "law is not a counsel, but a command ... of that person (whether man or court) whose precept contains in it the reason of obedience." Thomas HobBeS, DE CIVE: OR, THE CITIZEN 155 (Sterling P. Lamprecht ed., 1949). Following Hobbes' logic, Austin also asserted that positive international law is confounded with positive international morality: "the law obtaining between nations is not positive law: for every positive law is set by a given sovereign to a person or persons in a state of subjection to its author. ... [T] [Te law obtaining between nations is law (improperly so called) set by general opinion. The duties which it imposes are enforced by moral sanctions: by fear on the part of nations ... of provoking general hostility, and incurring its probable evils, in case they shall violate maxims generally received and respected." JOHN AUSTIN, THE PROVINCE OF JURISPRUDENCE DETERMINED 201 (B. Franklin 1970) (1885).

166. George P. Fletcher, How would the Bush Administration's Claims of Self-Defence, Used as Justifications for War Against Iraq, Fare Under Domestic Rules of Self-Defence?, FINDLAW.COM, Sept. 10, 2002, http://writ.news.findlaw.com/commentary/ 
employ unilateral force as a means of achieving national policy objectives well precedes the September 11 attacks. For instance, almost three decades ago, Reagan's "peace through strength" doctrine sought to include covert U.S. military activities in support of anti-communist insurgents within the selfdefence doctrine. The United States' doctrine to support "freedom fighters" was tested in Afghanistan, Ethiopia, Cambodia, Nicaragua and Angola. ${ }^{167}$ President Reagan justified such a policy as follows:

Our mission is to nourish and defend freedom and democracy, and to communicate these ideals everywhere we can.... We must not break faith with those who are risking their lives - on every continent, from Afghanistan ${ }^{168}$ to Nicaragua - to defy Soviet-supported aggression and secure rights which have been ours from birth. . . Support for freedom fighters is selfdefence .... ${ }^{169}$

The Reagan Doctrine, however, received a blatant rejection by the ICJ in the Nicaragua case. ${ }^{170}$ However, before the International Court of Justice's ruling, the Reagan Administration withdrew from the court's compulsory jurisdiction, which constituted a radical departure from the long-standing U.S. tradition of supporting international adjudication. ${ }^{171}$ Indeed, while the United States has called upon the ICJ many times in the past, it questioned the authority of the court as it appeared that the United States was likely to lose. ${ }^{172}$ The rationale of the United States' withdrawal from the proceedings is worth quoting:

[M]uch of the evidence that would establish Nicaragua's aggression against its neighbors is of a highly sensitive intelligence character. We will not risk U.S. national security by presenting such sensitive material in public or before a

167. Pete Du Pont, Freedom, Foreign Policy, and Public Opinion: A Strategy for Fostering Democracy, 11 FLETCHER F. WORLD AFF. 207, 207-08 (1987).

168. Ironically, it was the U.S. Central Intelligence Agency that armed, trained, and supported Osama Bin Laden and his organisation, today's greatest terrorist threat, against the then Soviet-supported regime in Afghanistan. See Marcelo G. Kohen, The Use of Force by the United States after the End of the Cold War, and its Impact on International Law, in UNITED STATES HEGEMONY AND THE FOUNDATIONS OF INTERNATIONAL LAW, supra note 30, at 206. This paradoxically confirms the cliché saying of "one man's terrorist is another man's freedom fighter."

169. President Ronald Reagan, State of the Union Address, (Feb. 6, 1985) in Du Pont, supra note 163, at 210; see also Charles Krauthammer, The Reagan Doctrine, TIME, June 24, 2001, available at http://www.time.com/time/magazine/article/0,9171,141478,00.html.

170. See Kohen, supra note 168 , at 201.

171. See Michael J. Glennon, Protecting the Court's Institutional Interests: Why Not the Marbury Approach?, 81 AM. J. INT'L L. 121, 125 (1987).

172. See Abram Chayes, Nicaragua, the United States, and the World Court, 85 Colum. L. Rev. 1445, 1447 (1985). 
Court that includes two judges from Warsaw Pact nations ... The right of a state to defend itself or to participate in collective self-defence against aggression is an inherent sovereign right that cannot be compromised by an inappropriate proceeding before the World Court. ${ }^{173}$

The United States' withdrawal from the court's compulsory jurisdiction and its rationale for doing so plainly illustrated that the Reagan administration cared little about the international legal framework governing the use of force and that it was also ready to ignore the procedures and institutions of international adjudication. ${ }^{174}$ Such unilateralism was maintained after the Cold War, as the United States unquestionably remained the world's sole superpower with its matchless economic and military capabilities. Although this era also witnessed significant multilateral enforcement actions, the United States, as the raids on Panama (1989), Iraqi intelligence (1993), Afghanistan and Sudan (1998) demonstrated, kept the door open for unilateral action whenever national interests so required. ${ }^{175}$ This approach was clearly expressed by President Bush Sr. in his West Point Military Academy speech in 1993:

At times, real leadership requires a willingness to use military force. And force can be a useful backdrop to diplomacy, a complement to it, or - - if need be - - a temporary alternative. . . . Using military force makes sense as a policy where the stakes warrant, where and when force can be effective, where no other policies are likely to prove effective, where its application can be limited in scope and time, and where the potential benefits justify the potential costs and sacrifice. ... The United States can and should lead, but we will want to act in concert, where possible involving the United Nations or other multinational grouping. ... A desire for international support must not become a prerequisite for acting, though.

173. U.S. WITHDRAWL From the PROCEedings INITIATEd by NiCARAGUA IN THE ICJ INTERNATIONAL COURT OF JUSTICE - TRANSCRIPT (Jan. 18, 1985) in DEP'T ST. BULL. March 1985, available at http://findarticles.com/p/articles/mi_m1079/is_v85/ai_3659121/pg_2 (emphasis added).

174. David P. Fidler, War, Law \& Liberal Thought: The Use of Force in the Reagan Years, 11 ARIZ. J. INT'L \& COMP. L. 45, 49-50 (1994).

175. See Gregory P. Harper, Creating a U.N. Peace Enforcement Force: A Case for U.S. Leadership, 18 FLETCHER F. WORLD AFF. 49, 49-51 (1994); Dadid Von Drehle \& R. Jeffrey Smith, U.S. Strikes Iraq for Plot to Kill Bush, WASH. POST, June 27, 1993, at A01, available at http://www.washingtonpost.com/wp-srv/inatl/longterm/iraq/timeline/062793.htm; Simon Chesterman, Rethinking Panama: International Law and the U.S. Invasion of Panama, 1989, in THE REALITY OF INTERNATIONAL LAW: ESSAYS IN HONOUR OF IAN BROWNLIE 57-95 (Guy S. Goodwin-Gill \& Stefan Talmon eds., 1999); James Bennet, U.S. Cruise Missiles Strike Sudan and Afghan Targets Tied to Terrorist Network, N.Y. TIMES, Aug. 21, 1998, available at http://partners.nytimes.com/library/world/africa.082198attack-us.html. 
Sometimes a great power has to act alone. ${ }^{176}$

The subsequent Clinton Administration simply elaborated upon the Bush Doctrine by envisioning three categories of national interests with corresponding guidelines as to the use of military force. ${ }^{177}$ The first category involved interests of fundamental importance to the U.S. survival, security and economic well-being. It was declared that "we will do whatever it takes to defend these interests, including - when necessary - the unilateral and decisive use of military power." but non-vital, U.S. interests that called for limited military means when success was likely, the costs and risks were commensurate with the threatened interests, and other means failed to achieve the objectives. The third category was related to the use of force for humanitarian interests, which, however, envisaged combat power only in urgent scenarios, while taking minimal risk with American troops. ${ }^{179}$

In essence, the doctrines follow a pattern of viewing military force as being complementary to diplomacy, or rather "an instrument of national policy," which was outlawed by the Kellogg-Briand Pact of 1928 and explicitly contravenes the U.N. Charter. While the doctrines express the desire for multilateral use of force, when the circumstances dictate otherwise unilateral force is considered to be a viable option for the protection of national interests. In other words, what is central to these doctrines is not respect for international legal norms, but decisive and quick victory with minimal financial and human cost. $^{180}$ This position was further confirmed, well before the September 11 attacks, by the Joint Vision 2020 report, released on May 30, 2000:

The complexity of future operations also requires that, in addition to operating jointly, our forces have the capability to participate effectively as one element of a unified national effort. This integrated approach brings to bear all the tools of statecraft to achieve our national objectives unilaterally when necessary, while making optimum use of the skills and resources provided by multinational military forces, regional

176. President George Bush, America's Role in the World, West Point, (Jan. 11, 1993), available at http://www.pbs.org/wgbh/pages/frontline/shows/military/force/bush.html (emphasis added).

177. See Kohen, supra note 168 , at 200 .

178. Peter L. Hays et al., American Defense Policy 288 (1997) (emphasis added).

179. The White House, a National Security Strategy of Engagement and ENLARGEMENT (Feb. 1996), available at http://www.fas.org/spp/military/docops/national/1996stra.htm; Charles Stevenson, The Evolving Clinton Doctrine on the Use of Force, 22 ARMED FORCES \& SECURTTY 511, 511-16 (1996).

180. See Kohen, supra note 168 , at 201; Stevenson, supra note 179 , at 516-19. 
and international organizations ... when possible. ${ }^{181}$

Following the atrocities of September 11, however, the same philosophy found its extreme form in Bush's loosely formulated press-conference answer that, in the face of deadly attacks such as those of September 11, "there are no rules." defence without due regard to multilateralism and the established criteria formulated in the case of Caroline. ${ }^{183}$ Rather, the war was engaged upon the belief that "military conflict, while not imminent, is inevitable, and that to delay would involve greater risk." 184 Nevertheless, the Bush Administration did not act upon Iraq's capacity or intention of attacking the United States or any other country. Instead, the emphasis was placed on a calculation of inevitability or probability. ${ }^{185}$ Moreover, the United States did not refer the matter to the Security Council as it was obvious that the recourse to warfare against Iraq would not be endorsed, which may itself constitute an answer to George W. Bush's memorable question, posed in his September 12, 2002 speech to the General Assembly: "[w]ill the United Nations serve the purpose of its founding, or will it be irrelevant?"186 At least for the purposes of the War on Iraq, the United Nations apparently became irrelevant to the Bush Administration.

The War on Iraq, unlike the military response directed at the Taliban regime (where Al Qaeda's responsibility for the September 11 attacks was amply demonstrated and the prospect of future attacks appeared to be imminent), did not receive extensive approval by the international community either, ${ }^{187}$ because the U.S. military venture did not even satisfy the requirements of anticipatory force. Indeed, as Falk rightly noted:

The facts did not support the case for pre-emption, as there was neither imminence nor necessity. As a result, the Iraq War seemed, at best, to qualify as an instance of preventive war, but there are strong legal, moral, and political reasons to deny both legality and legitimacy to such use of force. Preventive

181. JoINT ChIEFS OF STAFF, JoINT Vision 2020 (DEP'T DeF. 2000), available at http://www.fs.fed.us/fire/doctrine/genesis_and_evolution/source_materials/joint_vision_2020.p df (emphasis added); Randolph B. Persaud, Shades of American Hegemony: The Primitive, the Enlightened, and the Benevolent, 19 CONN. J. INT'L L. 263, 265 (2004).

182. Press Conference, (September 17, 2001) in Andrew Hurrell, "There are no Rules" (George W. Bush): International Order after September 11, 16.2 INT'L REL. 185, 186 (2002).

183. See Webster, supra note 63.

184. Jules Lobel, Preventive War and the Lessons of History, 68 U. PITT. L. REV. 307, 312 (2006).

185. Id.

186. George W. Bush, President's Remarks at the United Nations General Assembly, (Sept. 12, 2002), available at http://www.whitehouse.gov/news/releases/2002/09/20020912-1.html.

187. See Richard A. Falk, What Future for the UN Charter System of War Prevention?, 97 AM. J. INT'L L. 590, 592 (2003). 
war is not an acceptable exception to the Charter system, and no effort was made by the U.S. government to claim such a right, although the highly abstract and vague phrasing of the pre-emptive war doctrine in the National Security Strategy of the United States of America would be more accurately formulated as a "preventive war doctrine." But even within this highly dubious doctrinal setting, to be at all convincing the evidence would at least have to demonstrate a credible future Iraqi threat that could not be reliably deterred, and this was never done. ${ }^{188}$

The Iraq War, launched in March 2003, achieved military victory and ousted the Baathist regime within only three weeks, and with a minimal loss of American lives. ${ }^{189}$ Nonetheless, despite the failure of finding WMD and establishing a link between Al Qaeda and Iraq, not only does the occupation of Iraq continue, but the 2006 U.S. National Security Strategy reaffirms the preventive war doctrine by using the same rationale. ${ }^{190}$ In his introductory remarks to the 2006 Strategy, President George W. Bush declared that "[w]e fight our enemies abroad instead of waiting for them to arrive in our country. We seek to shape the world, not merely be shaped by it; to influence events for the better instead of being at their mercy."191 Most notably, the new National Security Strategy is far from answering any legitimate concern as to the spatial and temporal scope of the war undertaken against an undefined enemy. ${ }^{192}$ Indeed it was merely announced that " $[t]$ he war against terror is not over."193 The promise that "[t]he reasons for our actions will be clear, the force measured, and the cause just," 194 on the other hand, does not clarify the vague basis of the preventive war doctrine, which is again sought to be justified with no explicit reference to international law:

[W]e do not rule out the use of force before attacks occur, even if uncertainty remains as to the time and place of the enemy's attack. When the consequences of an attack with

188. Id. at 598.

189. See JoYNER, supra note 64 , at 187.

190. See The National Security Strategy of the United States of AMERICa (Mar. 2006) [Hereinafter NATIONAL SECURITY STRATEGY, available at http://www.whitehouse.gov/nsc/nss/2006/nss2006.pdf.

191. Id. at 3 (emphasis added).

192. See Christine Gray, The Bush Doctrine Revisited: .The 2006 National Security Strategy of the USA, 5 CHINESE J. INT'L L. 555, 563 (2006).

193. NATIONAL SECURITY STRATEGY, supra note 190, at 8 . The 2006 National Security Strategy shifted the focus from Iraq and North Korea to Syria and Iran, and put the latter on notice with a solemn warning that "any government that chooses to be an ally of terror, such as Syria or Iran, has chosen to be an enemy of freedom, justice and peace. The world must hold those regimes to account." Id. at 12 .

194. Id. at 23. 
WMD are potentially so devastating, we cannot afford to stand idly by as grave dangers materialize. This is the principle and logic of pre-emption. The place of pre-emption in our national security strategy remains the same. ${ }^{195}$

From this perspective it can well be argued that the United States can readily bypass international law without practically risking any diplomatic, economic or military sanctions due to its hegemonic capacity and privileged position in the Security Council. The lack of an independent and superior agency for the formulation and implementation of international law, ${ }^{196}$ in this context, illustrates the most notable weakness of international legal order ${ }^{197}$ relative to municipal legal systems where obedience to law may be coercively ensured. ${ }^{198}$ As noted, nation-states do not need any higher authority to enforce their law, because they are equipped with force monopoly and coercive machinery. ${ }^{199}$ Punishment may thus be meted out irrespective of the power status of individuals in society, i.e. nobody is immune from criminal liability for one's wrongdoing unless there are excuses or justifying conditions. In this respect, if the lethal force employed by an individual does not match any justification or excuse defences, such act will constitute a criminal offence for which

195. Id.

196. See John H. Crabb, An Introduction to Some International Law Concepts, 37 N.D. L. REV. 198, 201 (1961).

197. There is no doubt that international law is not as weak as it used to be. For instance, within the last century, international treaties and customs have produced a significant body of rules prohibiting atrocities, such as genocide, crimes against humanity and war crimes, or banning the use of biological and chemical weapons. Also, the atrocities committed in the former Yugoslavia and Rwanda galvanized the international will to establish two ad hoc tribunals, namely the International Criminal Tribunal for the former Yugoslavia (ICTY) and the International Criminal Tribunal for Rwanda (ICTR). The creation of the said tribunals, on the other side, significantly contributed in establishing the International Criminal Court (ICC), as a permanent instrument to investigate and prosecute international crimes. However, despite such achievements, states have often been unable or unwilling to properly apply international norms due to political considerations. See Roy S. Lee, The Rome Conference and Its Contributions to International Law, in THE INTERNATIONAL CRIMINAL CourT: THE MAKING OF THE ROME STATUTE Issues, Negotiations, Results 1-13 (Roy S. Lee ed., 1999); Nancy Amoury Combs, Establishing the International Criminal Court, 5 INT'L L. F. 77 (2003); Susan W. Tiefenbrun, Paradox of International Adjudication: Developments in the International Criminal Tribunals for the Former Yugoslavia and Rwanda, the World Court, and the International Criminal Court, 25 N.C. J. INT'L L. \& COM. REG. 551 (2000); Adrian Hole, The Sentencing Provisions of the International Criminal Court, 1 INT'L L.J. PUNISHMENT SEN'G 37 (2005).

198. Oppenheim notes that "compared with Municipal law and the means available for its enforcement, the Law of Nations is certainly the weaker of the two." OPPENHEIM, supra note 18, at 14 .

199. The sovereign, nonetheless, is not vested with unlimited authority, but is bound by the law; that is, the modern state system does not rest on the paradigm of legal despotism, wherein the power of the sovereign is unsusceptible of legal limitation. By contrast, the delegated state power is subordinate to the duty of protection: in Hobbes' language, "the end of obedience is protection." НовBES, supra note 108, at 156; Akashi, supra note 108, at 205; see also George H. Smith, The Theory of the State, 34 PROC. AM. PHIL. Soc'Y 181, 201-06 (1895). 
punishment must proportionately be inflicted.

In international law, on the other hand, not only is there no world government, ${ }^{200}$ but the Security Council is also technically and physically unable to use its Chapter VII mandates against the United States. Indeed, although the Security Council is vested with broad powers under the U.N. Charter, its effectiveness has always depended upon the Great Powers, which are often motivated by their political interests. ${ }^{201}$ Through the self-interested use of veto power, the Security Council has many times come to a stalemate to the detriment of international peace and security. ${ }^{202}$ For that reason, while international law envisages grave consequences for state aggression, the most untoward act in international relations, it ultimately lacks the teeth to impose obedience and prevent hegemonic state aggression. ${ }^{203}$

Regrettably, the U.N. Charter does not envisage a standing army at the service of the Security Council to undertake military action under Article 42 of the Charter. Instead, under Article 43, member states are obliged to provide armed forces to be employed on the call of the Council to enforce international peace and order. Yet this duty is to be realized "in accordance with a special agreement or agreements." 204 To date, political and ideological rifts among the Great Powers prevented the establishment of such an army. ${ }^{205}$ This not only paralyzed the whole collective security system during the Cold War period, but also hitherto precluded any possible enforcement action from being taken

200. See G. G. Fitzmaurice, The Foundations of the Authority of Intermational Law and the Problem of Enforcement, 19 MOD. L. Rev. 1, 2 (1956); F. H. HINSLEY, POWER AND THE PURSUTT of Peace: Theory and Practice in the History of Relations between States 336 (1963). 201 During the Cold War, due to a lack of cooperation among the Big Powers, the Security Council made very little resort to the collective security measures. Mandatory sanctions were merely imposed twice: Southern Rhodesia in 1966 and South Africa in 1977. The use of force was explicitly authorized only in the case of Korea and, despite its limited character, in the Congo during the early 1960s. See T. G. Weiss et AL., The United Nations and Changing World POlitics 30-31 (2004); D. M. MALONE, The UN SECURITY COUNCIL: From THE COLD WAR TO THE 21ST CENTURY 10 (2004).

202. See Amber Fitzgerald, Security Council Reform: Creating a More Representative Body of the Entire U.N. Membership, 12 PACE INT'L L. REv. 319, 330, 333-34 (2000).

203. Hans Kelsen, Introduction to the Problems of Legal Theory 108 (Bonnie Litschewski Paulson \& Stanley L. Paulson trans., 1992).

204. EDWARD H. LAWSON ET AL., ENCYCLOPEDIA OF HUMAN RIGHTS 1492 (1996).

205. In 1992, Boutros-Ghali, the then UN Secretary-General expressed such a need as follows: "Under the political circumstances that now exist for the first time since the Charter was adopted, the long-standing obstacles to the conclusion of such special agreements should no longer prevail. The ready availability of armed forces on call could serve, in itself, as a means of deterring breaches of the peace since a potential aggressor would know that the Council had at its disposal a means of response. Forces under Article 43 may perhaps never be sufficiently large or well enough equipped to deal with a threat from a major army equipped with sophisticated weapons. They would be useful, however, in meeting any threat posed by a military force of a lesser order." The Secretary-General, An Agenda for Peace, Preventive Diplomacy, Peacemaking and Peace-Keeping, 43, U.N. Doc. A/47/277=S/24111, (June 17, 1992), available at http://www.un.org/Docs/SG/agpeace.html. 
against a powerful state. ${ }^{206}$ It appears that military adventurism against nontangible threats may only be exercised by the Great Powers. At the domestic level, in contrast, abused individuals, such as battered women, tend to resort to lethal force in non-confrontational settings in large part because they lack viable options to effectively counter the endless cycle of violence.

\section{THE LEgal Status of THE PREVENTIVE WAR DOCTRINE: Is THERE AN EVOLVING CUSTOMARY NORM?}

While the preventive war doctrine might be conceived as an attempt to modify the use of force discourse, such legal change must widely be supported to take effect. ${ }^{207}$ Indeed, as stated in Nicaragua, "[r]eliance by a State on a novel right or an unprecedented exception to the principle might, if shared in principle by other States, tend towards a modification of customary international law." 208 Currently, there are deep divisions among states as to the exact contours of the legal framework governing the use of force. Yet it is important to note that the majority of the international community does not accept the concept of anticipatory self-defence, let alone the vaguely formulated preventive war doctrine. In other words, there has been no significant indication that a new customary rule is evolving regarding this matter. In contrast, hegemonic use of military force received significant resistance from most nations (including the majority of western states), a great majority of international law scholars and the Secretary General Kofi Annan. ${ }^{209}$ Although there have been some indications that states like Russia (against Chechen terrorism), China (against Taiwan), Iran (against the United States and Israel), North-Korea (against the United States), and Japan (against North Korea) do not disregard the possibility of employing anticipatory self-defence, it is still dubious whether they fully embrace the preventive war doctrine as articulated by the United States and its allies. ${ }^{210}$

Significantly, the stance of the ICJ has essentially remained the same since the September 11 attacks. In fact, in its decisions and advisory opinions, the ICJ avoided giving explicit opinions as to the legality of preventive force. ${ }^{211}$ In the Wall advisory opinion, the ICJ, making reference to its Nicaragua decision and the U.N. Declaration on Friendly Relations, preserved its strict reading of Article 51. ${ }^{212}$ Again, in Oil Platforms, the ICJ clearly maintained its

206. See Jane Stromseth et AL., CAN Might MAKe Rights? 21-23 (2006).

207. See Simpson \& Wheeler, supra note 55, at 123.

208. Military and Paramilitary Activities, supra note 50, I 207.

209. See Lobel, supra note 184, at 309; Iraq War Illegal, Says Annan, BBC NEWs, Sept. 16, 2004, available at http://news.bbc.co.uk/2/hi/middle_east/3661134.stm.

210. See Reisman \& Armstrong, supra note 53, at 538-46; Gray, supra note 192, at 566.

211. See Gray, supra note 192 , at 568 .

212. Legal Consequences of the Construction of a Wall in the Occupied Palestinian Territory, Advisory Opinion, 2004 I.C.J. 136, at 87-88 (July 2004), available at http://www.icjcij.org/docket/files/131/1671.pdf; Military and Paramilitary Activities, supra note 50, .11 187- 
approach by requiring the United States to prove Iran's responsibility for the attacks (the United States failed to prove this to the court's satisfaction), which had to be of such a nature to qualify as armed attacks within the meaning of Article 51. ${ }^{213}$

In the case of $D R C v$. Uganda, ${ }^{214}$ the court unfortunately expressed no view as to the legality of military force undertaken against an anticipated attack on the ground that the parties merely relied "on the right to self-defence in the case of an armed attack which has already occurred."215 The court nevertheless noted that while Uganda claimed to act in self-defence, it had failed to prove that DRC was actually involved in armed attacks against Uganda ${ }^{216}$ and/or that DRC was in support of anti-Ugandan rebel groups. ${ }^{217}$ The court further observed that Uganda's expressed objectives were essentially "preventative," that is, they were "to ensure that the political vacuum did not adversely affect Uganda, to prevent attacks from 'genocidal elements' ... to safeguard Uganda from irresponsible threats of invasion, [and] to 'deny Sudan the opportunity to use the territory of the DRC to destabilize Uganda." 218 The court thus concluded that the preconditions for the exercise of self-defence did not exist in the circumstances of the case: ${ }^{219}$ "Article 51 of the Charter may justify a use of force in self-defence only within the strict confines there laid down. It does not allow the use of force by a state to protect perceived security interests beyond these parameters. Other means are available to a concerned state, including, in particular, recourse to the Security Council.,"220

The unilateral use of force against Iraq also attracted serious criticism from Kofi Annan. In his annual address to the General Assembly, six months after Operation Iraqi Freedom, the Secretary-General expressed his concerns as to the preventive employment of force:

[It is argued that] States are not obliged to wait until there is agreement in the Security Council. Instead, they reserve the right to act unilaterally, or in ad hoc coalitions. This logic represents a fundamental challenge to the principles on which, however imperfectly, world peace and stability have rested for the last fifty-eight years. . . . The United Nations is by no means a perfect instrument, but it is a precious one. . . . [It aims] to save succeeding generations from the scourge of war, to reaffirm faith in fundamental human rights, to re-establish

90.

213. Oil Platforms, supra note 144, II 51.

214. Case Concerning Armed Activities on the Territory of the Congo (Dem. Rep. Congo v. Uganda), 2005 I.C.J. 116 (Dec. 19).

215. Id. at 124 .

216. Id.

217. Id. at 228.

218. Id. at 125 .

219. Id. at 126 .

220. Id. at 127-28 (emphasis added). 
the basic conditions for justice and the rule of law, and to promote social progress and better standards of life in larger freedom. The world may have changed ... but those aims are as valid and urgent as ever. ${ }^{221}$

In February 2003, Annan appointed a panel of eminent experts to assess common threats to collective security and the appropriateness of the unilateral use of force. The resultant report on Threats, Challenges and Change announced that although international law does not prohibit anticipatory military action taken against an imminent threat, ${ }^{222}$ the main question arises where the threat is not imminent but claimed to be real. The report clearly stated that:

[I]f there are good arguments for preventive military action, with good evidence to support them, they should be put to the Security Council, which can authorize such action if it chooses to. If it does not so choose, there will be, by definition, time to pursue other strategies, including persuasion, negotiation, deterrence and containment - and to visit again the military option. . . . For those impatient with such a response, the answer must be that, in a world full of perceived potential threats, the risk to the global order and the norm of nonintervention on which it continues to be based is simply too great for the legality of unilateral preventive action, as distinct from collectively endorsed action, to be accepted. Allowing one to so act is to allow all. . . . We do not favour the rewriting or reinterpretation of Article $51 .{ }^{223}$

A U.N. World Summit, held in September 2005, considered the controversial issue of whether the current collective security system should be modified. It was unambiguously underlined that "the relevant provisions of the Charter are sufficient to address the full range of threats to international peace and security." 224 Similarly, "the authority of the Security Council to mandate coercive action to maintain and restore international peace and security" was reaffirmed. ${ }^{225}$

221. The Secretary-General, Address to the General Assembly, delivered to the General Assembly (Sept. 23 , 2003), available

at http://www.un.org/webcast/ga/58/statements/sg2eng030923.htm.

222. The Secretary-General, Note by the Secretary-General on the Follow-up to the Outcome of the Millennium Summit, $\mathbb{1 1} 188$, delivered to the General Assembly, U.N. Cov.

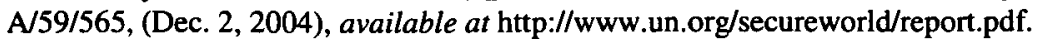

223. Id. TIH 190-92 (emphasis omitted).

224. General AsSEmbly, Resolutions and Decisions AdOpted by the GenERAl ASSEMBLY 15 (2003).

225. High-Level Plenary Meeting, Sept. 14-16, 2005, 2005 World Summit Outcome, $\mathbb{1 1 9 ,}$ 
The inhuman consequences of modern warfare, widespread practice of secret detentions, "enhanced interrogation techniques," and denial of fundamental human rights, particularly the outrages of Abu-Ghraib and Guantanamo, have similarly generated worldwide protests and disapproval of the preventive war doctrine. This is also a crucial element affecting the course of customary law creation. In other words, the stance of the United Nations, the state practice and the ICJ decisions are not the only relevant factors in assessing the customary evolution of the law on the use of force; non-state actors also have an important impact upon the process of customary norm formation. ${ }^{226}$ Indeed, universal protests against the hegemonic use of force undeniably influence the notion of opinion necessitates, an essential component for the crystallization of a customary norm. ${ }^{27}$

\section{CONCLUSION}

The main rationale of the temporal requirement, common to both criminal and international law, lies in the legitimate purpose of preventing unnecessary killings. Self-defence is a justified usage of deadly force against a present or imminent aggression; i.e. it is not an entitlement to cause irrevocable harm whenever the defendant subjectively believes in the necessity of lethal action to prevent an anticipated threat that might ripen into a real threat sometime in the future. Furthermore, the requirement of imminence may not merely be regarded as a "proxy" for establishing necessity; in contrast, imminence, necessity and proportionality are closely connected to one another and are meant to ensure that the private force is only resorted to when national/international authorities are not in a position to prevent an illegal aggression, and that the defensive lethal force is not abused or used for other motives rather than for defensive purposes. By requiring the would-be victim to take alternative measures to deal with an incipient threat, the imminence rule also ensures that a just balance is struck between the rights of the aggressor and defender.

The use of private aggression is too serious a phenomenon to be left to subjective judgments. Hence, within the context of battered women, it is to be reiterated that the solution does not lie in abolishing the legal categories that provide safeguards against arbitrary killings or vigilante actions. The institution of punishment is the prerogative of the state machine; battered women, in this sense, may not act as judges in their own causes and impose the death penalty upon the abusers who may well be acting under excusing or

U.N. Doc. A/RES/60/1, (Sept. 20, 2005).

226. See Jennifer Van Bergen \& Douglas Valentine, The Dangerous World of Indefinite Detentions: Vietnam to Abu Ghraib, 37 CASE W. RES. J. INT'L. L. 449, 451-52 (2006); Jens Meierhenrich, Analogies at War, 11 J.CONFLICT \& SEC. L. 1, 28-29 (2006); Asli U. Bali, Justice Under Occupation: Rule of Law and the Ethics of Nation-Building in Iraq, 30 YALE J. INT'LL. 431, 468 (2005).

227. Achilles Skordas, Hegemonic Intervention as Legitimate Use of Force, 16 MiNN. J. INT'L L. 407, 425 (2007). 
mitigating conditions, or who are likely to receive a less severe punishment, even in jurisdictions where the death penalty still exists. Therefore, focus should be shifted to the negligent state institutions that do not provide effective protection to the victims of abuse.

At the international level, the motives of the United States in attempting to alter the self-defence doctrine differ fundamentally from those of the battered women, for the former has never been the object of constant abuse or violence. Instead, the primary motive of the United States, in seeking to relax the traditional contours of self-defence, lies in its desire to have the upper hand in international relations by employing unilateral force as a potential instrument of national policy. However, preventive war doctrine has not hitherto received any significant international approval; rather, it aroused a legitimate concern that the doctrine might undermine the hard-won international accomplishment in abolishing warfare, which, as the preamble of the U.N. Charter stresses, has so far brought nothing but "untold sorrow to mankind." 228 If the United States and its allies are sincerely concerned about the ineffectiveness of international law in the face of new threats, then it is worth concluding with Habermas, who offers not only a practical, but also a durable solution:

In the face of enemies who are globally networked, decentralized, and invisible, the only effective kinds of prevention will be on other operative levels. Neither bombs nor rockets, neither fighter jets nor tanks will be of any help. What will help is the international networking of flows of information among intelligence services and prosecutorial authorities, the control of flows of money, and the rooting out of logistical supplies. . . . Other dangers which arise from failures of negligence in non-proliferation policies (concerning nuclear, chemical, and biological weapons) are at any rate better handled through stubborn negotiation and inspection than with wars of disarmament. ... 229 